\title{
Early life on land and the first terrestrial ecosystems
}

\author{
Hugo Beraldi-Campesi
}

\begin{abstract}
Terrestrial ecosystems have been largely regarded as plant-dominated land surfaces, with the earliest records appearing in the early Phanerozoic ( $<550 \mathrm{Ma})$. Yet the presence of biological components in pre-Phanerozoic rocks, in habitats as different as soils, peats, ponds, lakes, streams, and dune fields, implies a much earlier type of terrestrial ecosystems. Microbes were abundant by $\sim 3,500 \mathrm{Ma}$ ago and surely adapted to live in subaerial conditions in coastal and inland environments, as they do today. This implies enormous capacities for rapid adaptations to changing conditions, which is supported by a suggestive fossil record. Yet, evidence of "terrestrial" microbes is rare and indirect in comparison with fossils from shallow or deeper marine environments, and its record has been largely overlooked. Consequently, the notion that microbial communities may have formed the earliest land ecosystems has not been widely accepted nor integrated into our general knowledge. Currently, an ample record of shallow marine and lacustrine biota in $~ 3,500 \mathrm{Ma}$-old deposits, together with evidence of microbial colonization of coastal environments $\sim 3,450 \mathrm{Ma}$ ago and indirect geochemical evidence that suggests biological activity in $>3,400 \mathrm{Ma}$-old paleosols endorses the idea that life on land perhaps occurred in parallel with aquatic life back in the Paleoarchean. The rapid adaptations seen in modern terrestrial microbes, their outstanding tolerance to extreme and fluctuating conditions, their early and rapid diversification, and their old fossil record collectively suggest that they constituted the earliest terrestrial ecosystems, at least since the Neoarchean, further succeeding on land and forming a biomass-rich cover with mature soils where plant-dominated ecosystems later evolved. Understanding how life diversified and adapted to non-aquatic conditions from the actualistic and paleontological perspective is critical to understanding the impact of life on the Earth's systems over thousands of millions of years.
\end{abstract}

\section{Introduction}

\section{Definition of "terrestrial"}

Habitable, non-aquatic environments must have existed all throughout the geologic history of Earth unless its surface was entirely under water, which seems unlikely. The definition of a terrestrial environment may not be as trivial as it sounds. "Terrestrial" is defined here as non-aquatic environments. However, even fully aquatic ecosystems, such as lakes and coastal environments, cover a wide spectrum of mixed environments where aquatic and non-aquatic landscapes develop and overlap over time. Habitats above sea level include aquatic (ice-covered and ice-free lakes, ponds and wetlands, peats, rivers and streams, geothermal fields) and non-aquatic environments (especially areas with low rain regimes) that experience drastic changes governed by tectonic activity and climatic

Correspondence: hberaldi@unam.mx

Institute of Geology, UNAM, Ciudad Universitaria, Mexico DF 04510, Mexico conditions, including the rise and fall of sea level, glaciations, and rain regimes (e.g., Romans and Graham 2013). Microbes can be expected in all these environments and, in the long term, they may have strongly influenced the regional topography, sedimentation rates, sedimentary dynamics, and the reworking of previously emplaced materials. This might be difficult to interpret sometimes from the sedimentary record, especially in environments whose configuration and sedimentary dynamics can change in a relatively short time (days to decades), such as coastal areas (deltas, estuaries, lagoons, evaporitic flats, dunes, etc.; e.g., Hamblin and Christiansen 2007), going from aquatic to non-aquatic environments in a few centimeters or meters of rock strata.

Sedimentary deposits originating in fully aquatic environments (fluvial, lacustrine, shallow marine) can be further exposed to the atmosphere for long periods of time and undergo pedogenetic processes, which transform some of the original features of the deposit into a soil 
(e.g. Paul et al. 2001 and references therein). The rocks thus keep gross characteristics of the primary deposit but are overprinted with the in situ, secondary features derived from completely different environmental conditions. Besides, elucidating timescales at the outcrop scale is not always feasible and is frequently overlooked in less resolved regional studies. Ultimately, this has surely contributed to biases in the interpretation of the evolution of the biosphere. In this regard, the study of pedogenetic (e.g., development of horizons, hardpans or duricrusts, peds, and clay compositional and mechanical-e.g., slickensides-features, etc.) and microbial processes in spring and stream microbialites (e.g., travertines, tufas, sinters) and exposed sedimentary and rock surface habitats (endolithic habitats and cryptogamic covers), is of particular importance for the more comprehensive understanding of past life because these represent terrestrial habitats expected on ancient continental surfaces.

\section{Caution and re-interpretation of the rock record}

Through the integrative study of rocks and the understanding of the processes that formed them, including the fossil record and our ability to date materials isotopically, we have built a concept of the evolution of the geosphere and the biosphere (see compendiums by Schopf 1983; Canup and Righter 2000; Eriksson et al. 2004; Schieber et al. 2007; Van Kranendonk et al. 2007a; Kasting 2009; Taylor et al. 2009; Knoll et al. 2012), despite important and ongoing debate on the details. One key element in this picture is the inception of life, which has been interacting with and changing, maintaining, and recirculating most of the materials existing in the atmosphere and the supracrustal section of the Earth for over $\sim 80 \%$ of Earth's history. This scenario has been studied and interpreted over the years, aided by the technology available at the moment, not always correctly and also biased sometimes by the general consensus (e.g., Hallbauer 1975; Gray and Boucot 1994; Windley 2007). Also, our appreciation of the timing of geological phenomena (soil formation, seafloor spreading, mountain building, rock erosion, lake succession, etc.) may be difficult to relate to other global changes (e.g. rapid and profuse volcanism and rapid climatic oscillations coexisting with slow seafloor spreading and continental drift) when interpreting the rock record.

Besides the record being incomplete, the speed at which biology operates compared to geology implies that hiatuses of tens of millions of years (negligible in Pracambrian timescales), represented by only a few centimeters or meters of rock strata, bear enormous opportunities for biological developments and adaptations that may have not been preserved. This conceptualization of the speed at which biotic and geological events occur simultaneously requires a careful examination and reevaluation of Precambrian geological materials (aided by the advancement of scientific knowledge and technology around it) with a readiness to consider challenging ideas (e.g., Retallack 2013), especially when recognizing fossils or when trying to reconcile them with their paleoenvironments (Xiao and Knauth 2013).

The fossil record of microbes is largely related to aquatic environments, and while abundant morphological, chemical, and geochemical evidence of diverse, aquatic Archean life has reached wide acceptance and consensus, the existence of life on Precambrian lands is not always taken for granted. The historical perception of plants as the dominant group on the land, together with the first discoveries of macroscopic fossils only in Phanerozoic rocks and the inability to correctly interpret microbial and algal biosignatures, has perhaps infused the generalized understanding of "colonized" terrestrial ecosystems exclusively for plants (e.g., Bambach 1999). In some instances, even when the existence of Precambrian terrestrial ecosystems may be recognized, they are still treated doubtfully or not given adequate attention (Shear 1991; Behrensmeyer et al. 1992; DiMichele and Hook 1992; Gray and Shear 1992; Gray and Boucot 1994) even after previous and important discussions on the topic (e.g., Wright 1985; but see also Labandeira 2005).

The possible misinterpretation of terrestrial paleoenvironments and their relatively poor preservation in the sedimentary record does not necessarily mean that terrestrial life did not exist on the early continents. Today there is growing evidence indicative of nonaquatic environments colonized by microbes early in Earth's history, which is consistent with the extent of modern microbial life on analog "barren" lands (deserts, polar plains, alpine rocks, etc.) their outstanding diversity and metabolic capabilities, and by the great diversity and distribution of Precambrian microfossils, which is a reflection of the microbial ubiquity at that time.

\section{The setting for early life}

The oldest materials yet found in the Solar System occur in meteorites and are $~ 4,570 \mathrm{Ma}$ (Mega annum, million years) of age (Bouvier and Wadhwa 2010), which may serve as a starting point for the condensation of the first solids in our Solar System. By contrast, the oldest materials on Earth (zircon crystals) go back $\sim 4,400 \mathrm{Ma}$ (Wilde et al. 2001), leaving a hiatus of $\sim 170 \mathrm{Ma}$ in Earth's geological history. Regardless, it is assumed that the Moon was already formed before 4,400 Ma (Canup and Righter 2000; Yu and Jacobsen 2011) and that the Earth's nucleus, mantle, and lithosphere were already differentiated (Nelson 2004; Boyet and Carlson 2005). At least by $\sim 4,200 \mathrm{Ma}$, but perhaps $200 \mathrm{Ma}$ earlier, large 
water bodies were in place (Mojzsis et al. 2001; Nutman 2006; Cavosie et al. 2007, but see alternative views by Deming 2002), while granitic (continental) and basaltic (oceanic) crusts were constantly growing, resurfacing, and remelting, interacting with water in non-uniform regimes that evolved drastically from the Hadean to the Neoarchean (Komiya et al. 1999; Nutman et al. 2002; Myers 2004; Rino et al. 2004; Van Kranendonk 2004 and references therein; Furnes et al. 2007a; Adam et al. 2012), changing from plume-dominated to platedominated tectonics toward the late Paleoarchean (Van Kranendonk et al. 2007b). It is plausible then, that by the end of the heavy bombardment (Gomes et al. 2005; Hartmann et al. 2000) some $3,800 \mathrm{Ma}$ ago, the primitive lands and oceans were open niches ready for the pioneering and rapidly evolving microscopic life forms, for which occasional "sterilizing" perturbations may be irrelevant given the resilience and time scales at which biology operates compared to geology.

Although life may have appeared only a few hundred million years after Earth's accretion (e.g., Lopez-Garcia et al. 2006), sedimentary rocks older than $\sim 3,850 \mathrm{Ma}$ (Nutman et al. 1996; Ishizuka 2008; Nutman et al. 2010; O'Neil et al. 2011; Mloszewska et al. 2012), where biotic events are most likely to be imprinted, are uncommon on Earth. Yet, potential traces of life (e.g. biogenically precipitated carbonates) may even be present in this ancient record (Nutman et al. 2010), suggesting that life itself can be several million years older than the oldest known stromatolites and microfossils. Other putative biosignatures older than 3,500 Ma (carbonaceous spherules associated with apatite globules; see McKeegan et al. 2007; Papineau et al. 2010a, 2010b) are also controversial (see Myers 2001; van Zuilen et al. 2002; Fedo and Whitehouse 2002; Papineau et al. 2011) and may not imply a syngenetic timing of formation with the host rock. Biosignatures of particular interest would be those associated with biogenic banded iron formations (e.g., Dauphas et al. 2004; Trendall and Blockley 2004; Kappler et al. 2005; Konhauser et al. 2005; Koehler et al. 2010; Mloszewska et al. 2012) given their potential antiquity of $\sim 4,300 \mathrm{Ma}$ (O'Neil et al. 2009).

Microfossils, microbialites, and isotopic and molecular biomarkers indicate that prokaryotic life was abundant by 3,500-3,400 Ma ago in shallow and deep marine environments (Lowe 1980; Walter et al. 1980; Awramik et al. 1983; Schopf 1983; Walter 1983; Walsh, 1992; Walsh and Lowe 1985, 1999; Rasmussen 2000; Westall et al. 2001; Furnes et al. 2004; Shen and Buick 2004; Tice and Lowe 2004; Allwood et al. 2006; Banerjee et al. 2006; Westall et al. 2006a, 2006b; Ueno et al. 2006; Schopf et al. 2007 and references therein; Shen et al. 2009; Westall 2010; Wacey et al. 2011), which supports the notion that coastal and estuarine areas could have been very productive by that time and that photosynthesis was already operating (Awramik 1992; Rosing and Frei 2004; Tice and Lowe 2004; Buick 2008; Hoashi et al. 2009; Kato et al. 2009; Kendall et al. 2010), though perhaps not necessarily oxygenic (Kirschvink and Kopp 2008; Westall et al. 2011; Li et al. 2012).

Many different settings have been proposed as likely or "optimum" for the emergence and prosperity of life, ranging from deep-sea hydrothermal vents and geothermal springs, to land surfaces and mineral-water-air interphases (Baross and Hoffman 1985; Retallack 1986a; Holm 1992; Battistuzzi and Hedges 2009; Aller et al. 2010; Hazen and Sverjensky 2010; Mulkidjanian et al. 2012). However, one preferred environment where many of the oldest signs of life are found is shallow marine continental margins (see references in Schopf and Klein 1992). Whether this is a true fact or a consequence of the incompleteness/selectivity of the record is still to be resolved. However, in these coastal environments microbes were likely to have been periodically exposed and desiccated, as happens in most such environments today, and likely developed adaptations for long-term desiccation regimes (e.g., thick hygroscopic sheaths) and high UV radiation (e.g., living interstitially).

Some of the oldest examples of life activity, which come precisely from aquatic, shallow marine (Klein et al. 1987; Schopf and Klein 1992; Van Kranendonk et al. 2008; Westall 2010; Van Kranendonk 2011; Hickman and Van Kranendonk 2012), shallow lacustrine (Awramik and Buchheim 2009; Hickman and Van Kranendonk 2012), and intertidal environments (e.g., Noffke et al. 2006; Noffke 2010; Noffke et al. 2011; Westall et al. 2011), show signs of evaporation (e.g., Noffke et al. 2008; Westall et al. 2011; Hickman and Van Kranendonk 2012), which suggests that early microbial communities in shallow waters had to deal with periodic desiccation and UV radiation $>3,400 \mathrm{Ma}$ ago. This further implies adaptations to resist desiccation, salinity fluctuations, and UV radiation that could be successfully used even after prolonged desiccation. Dry conditions can be expected also for lacustrine and fluviatile environments. Desiccation allows dispersion by wind, which seems like a reasonable means for land colonization. Through this mode of dispersion, communities would tend to be at or near the surface instead of underground, even when migration to aquifers can occur. Perhaps environments with periodic subaerial exposure (especially estuarine and intertidal) were crucial scenarios for a biological transition from water to land.

Apparently not only prokaryotes were abundant in shallow Precambrian environments; the oldest eukaryotic-like fossils (acritarchs; Buick 2010) found so far (that perhaps needed oxygen for advantageous energetic and metabolic capabilities) are $\sim 3,200 \mathrm{Ma}$ old and were also present in estuarine environments (Javaux et al. 2010). This indicates 
that life achieved a relatively rapid global presence and had diversified enough (Kandler 1994; Altermann and Schopf 1995; Ueno et al. 2006; Blank 2009; David and Alm 2011) to occupy a wide variety of ecological niches by the Paleoarchean, even in places that may have been severely disturbed by asteroid impacts (see Walsh 1992 and references therein). Even greater biological diversity, ubiquity, abundance, and habitats are seen in the younger Proterozoic record (e.g., Schopf 1992a; Schopf and Klein 1992), for which rocks are better preserved and more abundant than Archean ones.

\section{The fossil record of terrestrial life}

The earliest remnants of continental crust may derive from $\geq 3,500$ Ma-old submillimeter zircons (Nutman 2006) and regional rock outcrops (Buick et al. 1995; Iizuka et al. 2006; Stern and Scholl 2010; Adam et al. 2012). Supplementary evidence for exposed lands may consist of thick soils developed on these ancient surfaces (Buick et al. 1995; Hoffman 1995; Ohmoto et al. 2007; Johnson et al. 2009, 2010). The further growth of continents and their sedimentary cover, implying extensive intracratonic terrestrial settings that remained relatively stable (although still affected by erosion, sea level changes, tectonics, and volcanism), is reflected in the ample record of paleosols onward (see study approaches and examples by Jackson 1967; Gay and Grandstaff 1980; Holland 1984; Aspler and Donaldson 1986; Grandstaff et al. 1986; Kimberley and Grandstaff 1986; Reimer 1986; Retallack 1986b; Farrow and Mossman 1988; Zbinden et al. 1988; Palmer et al. 1989; Holland 1992; Gall 1994; Macfarlane et al. 1994; Martini 1994; Retallack and Mindszenty 1994; Driese et al. 1995; Banerjee 1996; Ohmoto 1996; Prasad and Roscoe 1996; Gutzmer and Beukes 1998; Thiry and Simon-Coincon 1999; Rye and Holland 2000; Watanabe et al. 2000; Retallack 2001 and references therein; Yang and Holland 2003; Driese and Gordon-Medaris 2008; Pandit et al. 2008; Bandopadhyay et al. 2010). This record of old paleosols holds indirect proof of the early environmental conditions on Earth and early life on land.

Currently, the oldest and direct evidence of terrestrial life comes from 2,900-2,700 Ma-old (see age determination of Witwatersrand deposits in Kositcin and Krapez 2004; Zhao et al. 2006), organic matter-rich paleosols (Watanabe et al. 2000), ephemeral ponds (Rye and Holland 2000) and alluvial sequences, some of them bearing microfossils (Hallbauer and van Warmelo 1974; Mossman et al. 2008). Interestingly, their occurrence in such settings coincides with drastic changes in Earth's crustal configuration and the - perhaps abrupt-emplacement of large continental masses in the late Archean (Condie 2004; Eriksson and Martins-Neto 2004; Van Kranendonk 2004 and references therein; Hazen et al. 2012), a marked step in the oxygenation of the atmosphere (Kendall et al. 2010), and also with estimations of land colonization by microbes based on phylogenetic relationships (Battistuzzi et al. 2004). Although microbes could have colonized the land before this time, the Meso- to Neoarchean appears to be an important evolutionary time period for terrestrial microbial communities, perhaps linked to supercontinent growth (Santosh 2010) and the emergence of potential new habitats.

Later in time, the amount of organic matter-rich and possibly "biologically weathered" paleosols (Ohmoto 1996; Beukes et al. 2002; Driese and Gordon-Medaris 2008), terrestrial sedimentary structures of presumed biotic origin (Hupe 1952; Lannerbro 1954; Voigt 1972; Eriksson et al. 2000; Prave 2002), and microfossils themselves (Cloud and Germs 1971; McConnell 1974; Horodyski and Knauth 1994: Strother et al. 2011) drastically increased throughout the Proterozoic. Likewise, marine microfossils display increasing biological developments and adaptations (Knoll et al. 2006). Biotic diversity and abundance become even greater from the Neoproterozoic-Phanerozoic transition to the recent (see Zhuravlev and Riding 2001; Xiao and Kaufman 2006; Gaucher et al. 2010). This timeline suggests a rapid and global development of life on Earth, with life forms adapted to live on the land more than 2,000 Ma before the earliest fossil record of land plants (Heckman et al. 2001; Gensel 2008). Important events in this chronology are depicted in Figure 1.

\section{Functioning of primitive terrestrial ecosystems and cyanobacteria}

A conceptualization of the functioning of the ancient terrestrial biosphere necessarily requires a general understanding of modern, analog microbial communities to evaluate their living requirements, diversity, physiology, and environmental impact, and to characterize any potential biosignature that could be used to recognize them in the rocks. Modern terrestrial microbial communities are found worldwide and in a great variety of local conditions, in surface (solid rock, regolith) and subsurface (caves, groundwater, deep ground) environments (although the latter could be considered aquatic by some). However, it is unclear which one is more productive in terms of biomass (Pace 1997) and what metabolisms have dominated those systems-and to what extent-over geologic time scales (Sleep and Bird 2007).

An understanding of the biology and distribution of modern microbes, which are ubiquitous in today's Earth's biosphere (Figure 2), seems essential for an understanding of their ancient counterparts and their impact on early terrestrial ecosystems. Estimates of the genetic diversity and biomass distribution in drastically different environments (e.g., Garcia-Pichel et al. 2003; Lozupone and Knight 2007; Nemergut et al. 2011) depict the ample range of strategies 
that terrestrial organisms, particularly primary producers, have developed for living on the land. Oxygenic photoautotrophy seems to be a particularly important capability of terrestrial organisms, simply because their energy source (light), reductant power (water), and carbon source $\left(\mathrm{CO}_{2}\right)$ are readily available in these environments. In comparison, other primary producers (e.g., chemolithotrophs) are restricted to aqueous environments because they require soluble sources of reductants (e.g., $\mathrm{H}_{2}, \mathrm{Fe}^{2+}, \mathrm{H}_{2} \mathrm{~S}, \mathrm{HS}^{-}$) and exergonic reactions to maintain their metabolism (White 2000). Besides being restricted to aquatic environments, chemolithotrophs are also less energy-efficient than oxygenic photoautotrophs (DesMarais 2000; Madigan et al. 2003; Konhauser 2007), and less likely dominant in subaerial environments.

Cyanobacteria have been the only organisms that developed special pigments and enzymatic capabilities for using water as a source of electrons. This process has allowed them to live outside the water in any suitable environment, even where water might be a limiting factor, such as deserts (e.g., Potts and Friedmann 1981). Oxygenic photosynthesis also contributed to the oxidation of the atmosphere (both by sequestering $\mathrm{CO}_{2}$ and by producing $\mathrm{O}_{2}$ ), a global and ongoing process with profound geochemical, atmospheric, hydrological, and biological implications (e.g., Rosing et al. 2006; Och and Shields-Zhou 2012; Pufahl and Hiatt 2012). Cyanobacteria and other prokaryotes, can also fix gaseous nitrogen, which seems of great advantage for an independence from dissolved $\mathrm{N}$ species, such as $\mathrm{NH}_{4}$ and $\mathrm{NO}_{3}$ (Glass et al. 2009). The appearance of cyanobacterial akinetes (for $\mathrm{N}_{2}$ fixation) in the Paleoproterozoic (Tomitani et al. 2006) attests to this early adaptation. For organisms on the land, a limiting nutrient, such as P, can be supplied by dust deposition (Kennedy et al. 1998; Reynolds et al. 2001; McTainsh and Strong 2007), which may be an alternative process for replenishment of nutrient loss by runoff and 


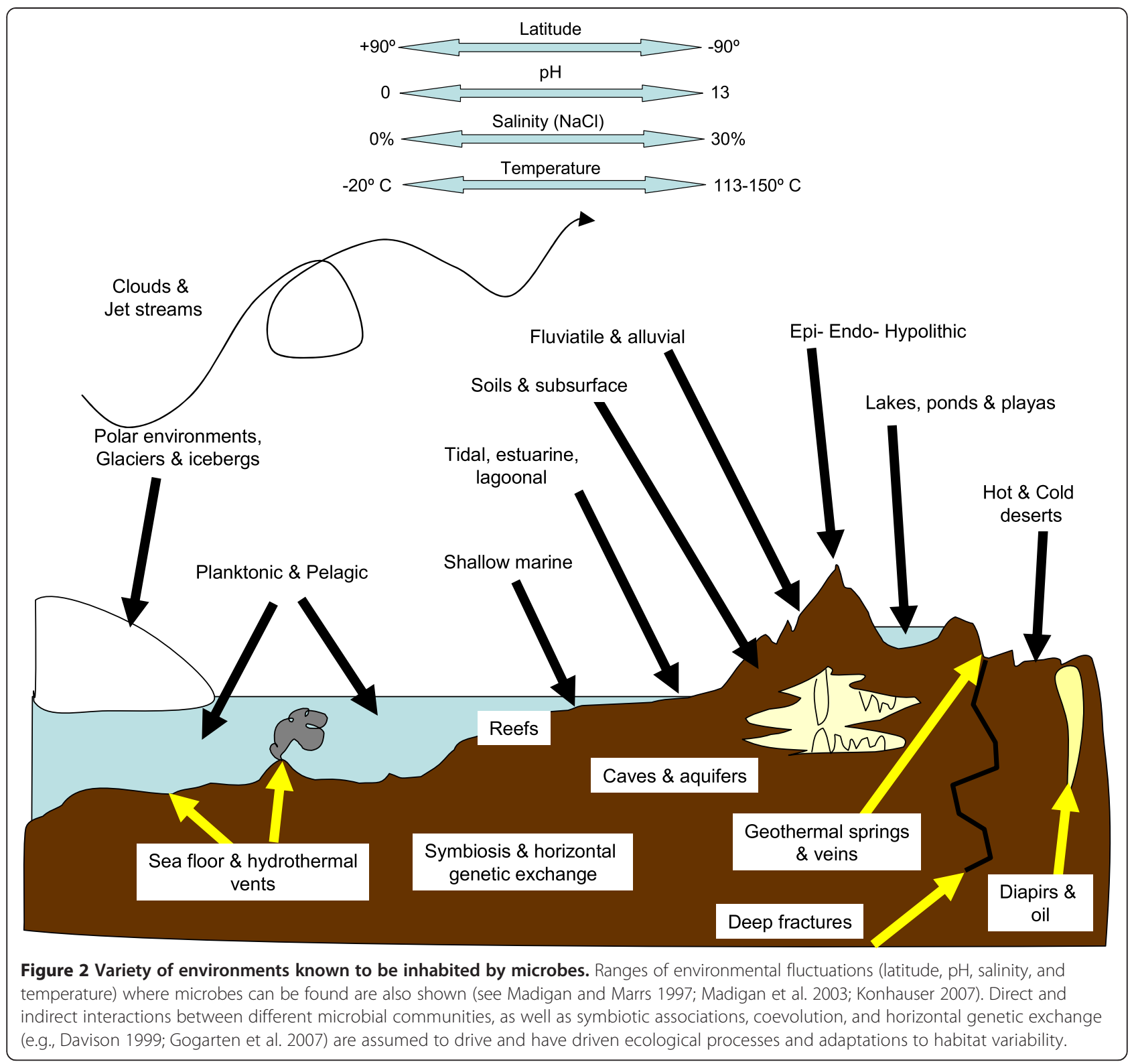

leaching in such environments (e.g. Beraldi-Campesi et al. 2009); S can also be acquired from minerals, aerosols, and as gaseous sources, likely present in the early atmosphere (Holland 1984). Thus, the nutritional requirements for oxygenic, photoautotrophic, primary producers seem not to have been a limiting factor for the colonization of the land. This idea has also been discussed in light of physiological and genetic characteristics of terrestrial microbes (Battistuzzi et al. 2004; Battistuzzi and Hedges 2009). Yet, an earlier chemotrophic way of life also needs to be considered (Shen and Buick 2004; Sleep and Bird 2007).

Particularly for the early terrestrial biota, a minimum set of adaptations to live subaerially must have included protection against radiation and desiccation effects. Adaptations such as thick polymeric sheaths with hygroscopic capacity against desiccation, efficient DNA repair mechanisms to restore metabolic activities as soon as water is available, and the production of UVshielding pigments are certainly successful strategies displayed by terrestrial cyanobacteria (Shephard 1987; Garcia-Pichel 1998; Yasui and McCready 1998; Potts 1999; Sinha and Hader 2002; Singh et al. 2010). Refined degrees of adaptation of terrestrial organisms include sunscreens that once placed within the extracellular sheaths, passively protect against UV radiation, even when the cell is dormant or dehydrated (Garcia-Pichel and Castenholz 1991; Gao and Garcia-Pichel 2011). Some of these strategies for living on the land likely evolved early and are partially displayed by microfossils (e.g., thick sheaths), which are sometimes associated 
with evaporitic sediments, in keeping with subaerial exposure (Schopf 1968; Hofmann 1976; Golubic and Campbell 1979; Awramik et al. 1983).

Modern cyanobacteria-driven communities can be found in any terrestrial environment ( $30 \%$ of modern Earth's surface area). They include endolithic communities (Friedmann 1980; Sun and Friedmann 1999; Büdel et al. 2004) and cryptogamic covers (CGC) on rocks and soils (Belnap and Lange 2001; Elbert et al. 2012). The latter have been shown to be very complex and dynamic and contain many distinct functional groups of prokaryotes and eukaryotes, ranging from primary producers to decomposers of specific materials, and grazers (Fritsch 1922; Fletcher and Martin 1948; Campbell 1979; Bamforth 1984, 2004; Garcia-Pichel et al. 2001; Nagy et al. 2005; Tirkey and Adhikary 2005; Chanal et al. 2006; Reddy and Garcia-Pichel 2006; Bates and GarciaPichel 2009; Neher et al. 2009; Meadow and Zabinski 2012 Bates et al. 2013). This diversity is variable based on local environmental conditions, but all CGC-albeit with few exceptions (e.g., Hoppert et al. 2004)-have in common the presence of cyanobacteria. This speaks for the evolutionary success that cyanobacteria have had over other microbes throughout time.

Although fossil analogs of CGC have been discovered in ancient sediments (Simpson et al. 2010; BeraldiCampesi et al. 2011; Retallack 2009, 2011; Sheldon 2012), it is unknown what their microbial composition might have been. However, morphological similarities between modern and fossil counterparts are remarkable (Schieber et al. 2007; Noffke 2010). Morphological resemblance between fossils and recent analogs suggests that cyanobacteria are indeed a very old group of bacteria (see Golubic and Seong-Joo 1999) and that at least some morphological traits have been maintained over time (Golubic and Hofmann 1976; Golubic and Campbell 1979; Schopf 1992b). Moreover, as cyanobacteria are such an old group and are so well adapted to colonizing unstable sediments (Booth 1941; Campbell et al. 1989; Mazor et al. 1996; Belnap and Gillette 1998; Malam Issa et al. 2001; Hu et al. 2002; Garcia-Pichel and Wojciechowski 2009), even where available water is scarce and there is considerable UV radiation (Fleming and Castenholz 2007; Giordanino et al. 2011), it is likely that they were also primordial components on land surfaces (Campbell 1979) and influenced the formation of sedimentary biostructures and textures represented in fossil examples (e.g., Prave 2002; Schieber et al. 2007; Noffke, 2011). The antiquity of cyanobacteria has been also estimated by molecular clock analyses of genomic distances to be $\sim 3,000 \mathrm{Ma}$ (Battistuzzi and Hedges 2009; Schirrmeister et al. 2013), which moreor-less coincides with the age of the oldest terrestrial microfossils (Mossman et al. 2008). This timing, however, may vary depending on the calibration points used for constructing phylogenies and the extent of horizontal gene transfer. Lastly, the capacity of chlorophyll $a$ to absorb higher photonic energies to split water in comparison to other photosynthetic bacteriochlorophylls (Xiong et al. 2000) may be the result of selective pressures to use the shorter wavelengths that reached the Precambrian surface where cyanobacteria had to dwell, a capacity not seen in purple or green phototrophic bacteria that use less energetic wavelengths in submerged/ shielded habitats. Thus, from a multi-angular perspective cyanobacteria seem the perfect candidates for the colonization of the earliest lands.

As mentioned above, most CGC have in common the presence of filamentous cyanobacteria. One property of these morphotypes is that they can glide through interstitial spaces using hollow hygroscopic sheaths of mucilage as trails, to shield themselves against radiation, to find their optimum light regime, or to track water (Garcia-Pichel and Pringault 2001). The nature of the filamentous members of these communities also provides more surface area and tension for fastening and binding disaggregated particles (Garcia-Pichel and Wojciechowski 2009). Polysaccharides secreted extracellularly provide additional cementing force to the entire organo-mineral framework, resulting in the formation of a (crust/mat) stable microenvironment. The intrinsic characteristic of filamentous microbes to form cohesive layers at sedimentary surfaces is also known to substantially decrease wind and water erosion in modern arid and semiarid areas of the world (Belnap and Gillette 1998; Belnap and Lange 2001). Although some erosive forces may surpass the tear resistance of CGC in high-energy systems (e.g., Corcoran and Mueller 2004), this property of microbes has been invoked to explain the stability of thick, Precambrian siliciclastic sedimentary sequences (Dott 2003) and the soft deformation properties of microbial mat-like structures (see references in Schieber et al. 2007). This is an important property of microbes for the functioning of siliciclastic ecosystems, and together with the presence of mature and organic-rich soils and microfossils in old Proterozoic strata (see references above), suggests that abundant "cryptogamic" covers were present on Precambrian lands, similar to those covering polar and arid areas of the world today. The addition of new members to these communities over time (most importantly algae and fungi, but also grazers) is expected and may be used to explain increasing weathering rates of the continents (Kennedy et al. 2006) and abrupt changes in the global balance of the $\mathrm{C}$ cycle in the Neoproterozoic (Knauth and Kennedy 2009).

\section{Other microbial components}

Judging from the rapid achievement of diversity and distribution of early microbial biota and from microbial successions seen in modern "barren" lands (e.g., Sigler 
et al. 2002; Schmidt et al. 2008; Fierer et al. 2010), it is expected that heterotrophic organisms were also part of land communities, as they seem to be an inevitable component in this type of consortia. Under this perspective, primitive microbial ecosystems cannot be understood as composed only of autotrophic primary producers, but also a myriad of other microbes finding their niche within such pre-existent microenvironments. For example, actinobacteria in modern CGC not only degrade large quantities of organic exudates from cyanobacteria, a process which influences the $\mathrm{C}$ cycle, but they also seem to be structural components of these sedimentary biostructures (e.g., Reddy and GarciaPichel 2006). The same applies to other bacteria (e.g., Bacteroidetes and Proteobacteria) that secrete large quantities of mucopolysaccharides, which aid in gluing soil particles together and may also have a critical role in the hydraulic conductivity of the surface substrate (Rossi et al. 2012). One of the most important eukaryotic component of of modern CGC are fungi, which must have played a key role in the colonization and weathering of bare rocks in the past (with symbiont cyanobacteria or algae), as well as in the successive development of vascular plants on the land (Smith and Read 2008) and in a radical change toward more "modern" terrestrial ecosystems (Blackwell 2000; Heckman et al. 2001; Taylor et al. 2009. See also Gadd 2006).

Although the timing of the origin of these organisms is unknown, terrestrial microbes can certainly drive important chemical transformations in soils (Keller and Wood 1993; Schwartzman and Volk 1989; Chenu and Stotzky 2002; Ehrlich 2002; Chorover et al. 2007) and endolithic habitats (Konhauser et al. 1994; Sun and Friedmann 1999; Büdel et al. 2004; Omelon et al. 2006) that may have operated in the past. These include affecting the reactivity of mineral surfaces with secreted metabolites (Geesey and Jang 1990; Welch et al. 1999), changing the $\mathrm{pH}$ and redox potential of the microenvironment (Bennett et al. 2001), or secreting metal ligands and other organic complexes that react with solutes and minerals (Keller and Wood 1993; Schwartzman and Volk 1989; Barker et al. 1998; Welch et al. 1999; Bennett et al. 2001). These mechanisms seem to play a fundamental role in biogeochemistry (weathering, clay formation, nutrient bioavailability, metal concentration and bioavailability, mineral formation or transformation, etc.), and their effects may also be used to trace microbial geochemical biosignatures in the rock record (BeraldiCampesi et al. 2009). Additionally, the process of soil formation and maturation is usually understood as aided by biology (Keller and Wood 1993; Schwartzman and Volk 1989; Brady and Weil 2008) and differentiated from abiotic regolith development, and involves a critical step prior to plant and animal colonization of the land. All these characteristics displayed by modern CGC could be expected from ancient analog communities, although with variations in the occurrence and magnitude dictated by their limiting factors.

\section{Dust}

The mechanism of dust formation, transport, and deposition reflects one important aspect of the functioning of terrestrial ecosystems because dust can only be formed on the land and because microbes (along with water adhesion and neo-cementation of particles with salts and clays) can stabilize fine dust particles through trapping and binding (e.g., Dong et al. 1987; Liu et al. 1994; Williams et al. 1995; Belnap and Gillette 1998; $\mathrm{Hu}$ et al. 2002). Thus, dust production can potentially be regulated by microbes (and other encrusting processes) depending on their degree of development. The more developed, the less dust production.

Dust is an important carrier of nutrients, and its retention on the ground might influence the budget and delivery of those nutrients locally or to other distant ecosystems, such as happens in modern marine environments via deposition of huge loads of dust (Jickells et al. 2005). The capacity of microbes to trap and bind particles has been demonstrated for numerous underwater and subaerial environments (Gunatilaka 1975; Zhang 1992; Takeuchi et al. 2001; Altermann 2008; Gradzinski et al. 2010; Williams et al. 2012). If microbes were responsible for much of the global dust capture, retention, and lixiviation on the early continents, recycling effects may have had profound implications for the evolution of global ecosystems through geologic time, as well as for important climatic processes, such as those rooted in atmospheric albedo variations (Harrison et al. 2001; Jickells et al. 2005; Lau et al. 2006).

Finally, dust is also a carrier of microbes and viruses (Abed et al. 2011; Al-Bader et al. 2012), which implies a means for biological dispersion that must have been operating continuously and over long distances in the past, amplifying the potential biogeography of biological entities over vast areas of the oceans and continents. Although the rate of survival and the success of foreign airborne mixed communities on aquatic environments, barren or already colonized surfaces is not known, it is plausible that such a mechanism was vital for the colonization of the early continents and the increase in ecological complexity and genetic exchange (e.g., Gogarten et al. 2007).

\section{Underground realm}

The underground realm (geothermal veins, aquifers, soil subsurface, all types of caves) should also be considered potential continental habitats for early terrestrial life, as life is abundant there today (e.g., Ghiorse and Wilson 
1988; Barton and Northup 2007; Engel 2010). The Precambrian record of caves (e.g., karstic environments) or underground aquifers (detected through nodules and concretions in the rocks) is far less known than the typical shallow marine or lacustrine environments (see examples of karstic and underground environments in Nicholas and Bildgen 1979; Schau and Henderson 1983; Glover and Kah 2006; Skotnicki and Knauth 2007; Rasmussen et al. 2009). Nevertheless, these environments must have existed throughout Earth's history, and thus, terrestrial biotas could have adapted to live in those conditions back in the Precambrian (Rasmussen et al. 2009).

In contrast to the most typical subaerial, light-driven primary producer communities, underground microbes require a chemosynthetic metabolism for primary productivity, perhaps relying on the oxidation of sulfur and iron compounds to support growth and continuity, as these are the main energy sources in such environments (Sarbu et al. 1996; Chen et al. 2009; Porter et al. 2009). Because these metabolic pathways are less energetic than photosynthesis, life underground is expected to have been slow-growing, less dynamic in terms of diversity and interactions, and more geographically contained than, for example, subaerial phototrophs. Nevertheless, early underground dwellers may have impacted the subsurface realm (cave formation, buried oil and dissolved organic matter consumption, methane production, etc.) and contributed to the neoformation and dissolution of minerals over the long term, as well as to the generation of gaseous byproducts (e.g., $\mathrm{H}_{2} \mathrm{~S}, \mathrm{CH}_{4}, \mathrm{CO}_{2}$ ) that could be important for geochemical processes on the surface and ultimately for distant communities and global biogeochemical recycling. Moreover, this type of environments could have been better protected from drastic and global crisis than subaerial ones, and thus have functioned as living reservoirs that could later exploit surface environments.

\section{A note on biosignatures}

Imprints of life in rocks can be formed in various ways and can be recognized as long as the rocks are preserved and accessible. Although this "fossil" record decreases in outcrop abundance the older the rocks are (basically due to burial, erosion, subduction, and metamorphism), biosignatures can be found in sedimentary rocks (Schopf 1983; Schopf and Klein 1992; Schieber et al. 2007; Noffke 2010), but also in igneous (Banerjee et al. 2006; Furnes et al. 2004, 2007b; Fliegel et al. 2010) and metamorphic (Franz et al. 1991; Hanel et al. 1999: Squire et al. 2006; Bernard et al. 2007; Schiffbauer et al. 2007, 2012; Schiffbauer and Xiao 2009; Zang 2007) rocks of all ages.

Preservation will always be favored in underwater settings, especially if biological materials are buried quickly, the sediment is fine grained, and the conditions are overall reducing (anoxic). All of these factors promote rapid mineralization and replacement of biological materials (Farmer 1999; Zonneveld et al. 2010; Allison and Bottjer 2011; Lalonde et al. 2012) which can preserve the morphology and organic remains, although this does not mean that preservation always happens (Zonneveld et al. 2010 and references therein). Unless protected, organic matter tends to degrade basically by photo-chemical degradation (if exposed to light), chemical bond breaking, biological recycling, mechanical maceration and dissolution. If body fossils are preserved, the lack of diagnostic morphologies for most bacteria and the possible existence of abiotic, microbe-like morphologies (e.g., García-Ruiz et al. 2002, Garcia-Ruiz et al. 2003) make their determination a challenge. Yet, their presence in a suitable geological context and association with sedimentary biostructures may be used as criteria for biogenicity. Molecular biomarkers in hydrocarbons that can be correlated with extant organisms (e.g., Summons et al. 1999) also require careful confirmation of syngenicity for a correct interpretation (Rasmussen et al. 2008; Brocks 2011).

If limiting factors are at play, microbial communities may not develop sufficient biomass to leave behind a biosignature (either chemical, geochemical, mineralogical, or morphological). Water, for example, which is the most basic requirement for survival and reproduction, tends to be a limiting factor on the land compared to a permanent water body. If microbial growth is thus limited, the amount of cells and biomass that can be preserved decreases. Thus, organisms with access to unlimited water resources would be able to grow larger communities and have more possibilities for fossilization, in contrast to terrestrial microbes that depend on dew or rain for their survival and maintenance. For example, the thickness and cohesiveness of a marine-intertidal microbial mat (see Bauld 1981; Bauld et al. 1992) are greater than in a mature biological soil crust (Belnap and Lange 2001), thus the latter will be less prone to fossilization than the marine one. Nevertheless, under favorable climates and landscapes, these too could be preserved (e.g., Prave 2002). Studies on biosignatures left behind by terrestrial microbial communities are needed for comparison against the yetto-explore rock record.

\section{Conclusions}

As the Earth was evolving, gradual degassing and accumulation of liquid water at its surface differentiated aquatic and non-aquatic environments. Because terrestrial environments have always existed, it is possible that life evolved on the land (including in lakes, rivers, streams, and flooding areas) as early as aquatic life itself (see Retallack 1986a and references therein). In any case, 
living on the land must have required particular adaptations, such as the capability to acquire nutrients and energy sources outside the aquatic realm, the development of molecular repairing mechanisms, and protection against radiation and desiccation. These adaptations were certainly developed by cyanobacteria, a group with a very old biologic lineage and one of the most conspicuous and successful primary producers on Earth (e.g., Whitton and Potts 2000; Herrero and Flores 2008).

Direct and indirect evidence pointing to inhabited terrestrial environments by the Paleoarchean (Johnson et al. 2009, 2010) and the following eras (Stüeken et al. 2012), along with substantive evidence of terrestrialization from the Neoarchean onward (Hallbauer and van Warmelo 1974; McConnell 1974; Horodyski and Knauth 1994; Gutzmer and Beukes 1998; Rye and Holland 2000; Watanabe et al. 2000; Prave 2002; Rasmussen et al. 2009), strongly implies that functional terrestrial ecosystems originated well back in the Precambrian. The implications for such colonization have not been completely understood, but the effects of microbial life on land processes that affect the atmosphere, the lithosphere, and the hydrosphere, are widely diverse and act at all scales. Two main consequences derived from the activities of land biota are the continuous oxygenation of the atmosphere (with consequences for the stratification of the oceans, the formation and maintenance of the ozone layer, and the precipitation of oxides, among others) and the weathering of the continents (Holland 1984; Catling et al. 2001; Stüeken et al. 2012), which indirectly and directly affect marine ecosystems. In contrast to marine biota, which indirectly affect terrestrial ecosystems through atmospheric processes (including gas composition and climate), the establishment of life on the land has an enormous significance for the evolution of the planet through time because gaseous byproducts, such as oxygen produced on the land would be released directly into the atmosphere and not dissolved in the oceans first. Once in the atmosphere oxygen would react with reduced species before starting to accumulate and produce a geochemical signature in marine sediments. Thus, land-based life could have been pivotal for the early oxygenation of the atmosphere, which later affected the oceans as well. A more direct influence of land-based communities over aquatic ones would be the production of dust, clays and leachates on the continents (Kennedy and Wagner 2011 and references therein), which would then be carried by rivers and wind into the oceans, and thus increasing the heterogeneity of materials and solutes delivered into oceanic ecosystems and having either beneficial or detrimental consequences for marine life. Yet, an overall retention of sediments on the land via microbial stabilization would be expected for detritic sediments in places with well-developed cryptogamic covers. Finally, it is expected that the time span from the inception of microbial land-based life to the evolution of the first plant ecosystems took long enough $(2,000-2,500 \mathrm{Ma})$ for coastal and inland settings to be transformed into organic- and nutrient-rich substrates that could later be exploited by more evolved communities and organisms toward the Neoproterozoic-Phanerozoic transition.

In general, the logical transition from cyanobacteria (and other bacteria and archea), to algae (and protists and fungi), to non-vascular plants, to vascular plants, may still be valid, but the timing of those evolutionary steps needs to be updated with the latest pertinent information available. The notion that the land was virtually sterile in the Precambrian (e.g., Bambach 1999; Blackwell 2000; Corcoran and Mueller 2004; Nesbitt and Young 2004; Gensel 2008) underestimates the impact that microbes could have had on the biosphere. More importantly, the idea the land was first colonized by plants and that they formed the earliest terrestrial ecosystems should be abandoned completely. That is not to say that the advent of plants in the Phanerozoic did not have strikingly enhanced effects on continental weathering, soil formation, and oxygenation of the atmosphere (Labandeira 2005; Taylor et al. 2009), but neglecting the existence of microbial, Paleoarchean-to-recent terrestrial ecosystems would impede a realistic understanding of the evolution of the biosphere and its influence on the geo-atmo-hydrosphere over time.

\section{Competing interests}

The author declares that there are no competing interests.

\section{Acknowledgments}

I am grateful to Kathleen E. Pigg, Anthony R. Prave, Gregory J. Retallack, Nora Noffke, Fernando Ortega Gutiérrez, Dominic Papineau, Marcela Martínez Millán, and Kelaine Ravdin for their important comments and improvements to this paper. I also thank the editors of Springer and Bettina Weber and Jayne Belnap for organizing and editing this special volume. I also thank the people from SIOV (Seminario Interdisciplinario del Origen de la Vida) at UNAM for fruitful discussions on critical aspects of this topic.

Received: 18 October 2012 Accepted: 30 January 2013

Published: 23 February 2013

\section{References}

Abed RMM, Ramette A, Hübner V, De Dekker P, de Beer D (2011) Microbial diversity of eolian dust sources from saline lake sediments and biological soil crusts in arid Southern Australia. FEMS Microbiol Ecol 80(2):294-304

Adam J, Rushmer T, O'Neil J, Francis D (2012) Hadean greenstones from the Nuvvuagittuq fold belt and the origin of the Earth's early continental crust. Geology 40:363-366

Al-Bader D, Eliyas M, Rayan R, Radwan S (2012) Air-dust-borne associations of phototrophic and hydrocarbon-utilizing microorganisms: promising consortia in volatile hydrocarbon bioremediation. Environ Sci Pollut R 19(9):3997-4005

Aller JY, Aller RC, Kemp PF, Chistoserdov AY, Madrid VM (2010) Fluidized muds: a novel setting for the generation of biosphere diversity through geologic time. Geobiology 8:169-178

Allison PA, Bottjer DJ (2011) Taphonomy: bias and process through time. In: Allison PA, Bottjer DJ (eds) Taphonomy: process and bias through time. Topics in geobiology, vol. 32. Springer, New York, pp 1-17 
Allwood AC, Walter MR, Kamber BS, Marshall CP, Burch IW (2006) Stromatolite reef from the Early Archaean Era of Australia. Nature 441:714-718

Altermann W (2008) Accretion, trapping and binding of sediment in Archean stromatolites-morphological expression of the antiquity of life. In: Botta $\mathrm{O}$ Bada J, Gómez EJ, Javaux E, Selsis F, Summons R (eds) Strategies of life detection. Space Sciences Series of ISSI, vol. 25. Springer, New York, pp 55-79

Altermann W, Schopf JW (1995) Microfossils from the Neoarchean Campbell Group, Griqualand West Sequence of the Transvaal Supergroup, and their paleoenvironmental and evolutionary implications. Precambrian Res 75:65-90

Aspler LB, Donaldson JA (1986) Paleoclimatology of Nonacho Basin (Early Proterozoic), Northwest Territories, Canada. Palaeogeogr Palaeoclimateol Palaeoecol 56:17-34

Awramik S (1992) The oldest records of photosynthesis. Photosynth Res 33:75-89

Awramik SM, Buchheim HP (2009) A giant, Late Archean lake system: the Meentheena Member (Tumbiana Formation; Fortescue Group), Western Australia. Precambrian Res 174:215-240

Awramik SM, Schopf JW, Walter MR (1983) Filamentous fossil bacteria from the Archean of Western Australia. Precambrian Res 20:357-374

Bambach RK (1999) Energetics in the global marine fauna: a connection between terrestrial diversification and change in the marine biosphere. Geobios 32 (2):131-144

Bamforth SS (1984) Microbial distributions in Arizona deserts and woodlands. Soil Biol Biochem 16(2):133-137

Bamforth SS (2004) Water film fauna of microbiotic crusts of a warm desert. J Arid Environ 56:413-423

Bandopadhyay PC, Eriksson PG, Roberts RJ (2010) A vertic paleosol at the Archean-Proterozoic contact from the Singhbhum-Orissa craton, eastern India. Precambrian Res 177(3-4):277-290

Banerjee DM (1996) A lower Proterozoic paleosol at BGC-Aravalli boundary in south-central Rajasthan. India J Geol Soc 48:277-288

Banerjee NR, Furnes H, Muehlenbachs K, Staudigel H, de Wit MJ (2006) Preservation of ca. 3.4-3.5 Ga microbial biomarkers in pillow lavas and hyaloclastites from the Barberton Greenstone Belt, South Africa. Earth Planet Sci Lett 241:707-722

Barker WW, Welch SA, Chu S, Banfield JF (1998) Experimental observations of the effects of bacteria on aluminosilicate weathering. Am Mineral 83:1551-1563

Baross JA, Hoffman SE (1985) Submarine hydrothermal vents and associated gradient environments as sites for the origin and evolution of life. Orig Life 15:327-345

Barton HA, Northup DE (2007) Geomicrobiology in cave environments: past, current and future perspectives. J Cave Karst Stud 69:163-178

Bates ST, Garcia-Pichel F (2009) A culture-independent study of free-living fungi in biological soil crusts of the Colorado Plateau: their diversity and relative contribution to microbial biomass. Environ Microbiol 11(1):56-67

Bates ST, Clemente JC, Flores GE, Walters WA, Wegener-Parfrey L, Knight R, Fierer N (2013) Global biogeography of highly diverse protistan communities in soil. ISME Jour 7:652-659

Battistuzzi FU, Hedges SB (2009) A major clade of prokaryotes with ancient adaptations to life on land. Mol Biol Evol 26:335-344

Battistuzzi FU, Feijao A, Hedges SB (2004) A genomic timescale of prokaryote evolution: insights into the origin of methanogenesis, phototrophy, and the colonization of land. BMC Evol Biol 4(44):1-14

Bauld I (1981) Geobiological role of cyanobacterial mats in sedimentary environments: production and preservation of organic matter. BMR J Aust Geol Geophys 6:307-317

Bauld J, D'Amelio E, Farmer JD (1992) Modern microbial mats. In: Schopf JW, Klein C (eds) The Proterozoic biosphere. Cambridge University Press, New York, pp 261-269

Behrensmeyer AK, Damuth JD, DiMichele WA, Potts R (1992) Terrestrial ecosystems through time: evolutionary paleoecology of terrestrial plants and animals. University of Chicago Press, Chicago II

Belnap J, Gillette DA (1998) Vulnerability of desert biological soil crusts to wind erosion: the influences of crust development, soil texture, and disturbance. J Arid Environ 39:133-142

Belnap J, Lange OL (2001) Biological soil crusts: structure, function, and management. Ecological Studies Series, vol. 150. Springer, Berlin

Bennett PC, Rogers JR, Choi WJ (2001) Silicates, silicate weathering, and microbial ecology. Geomicrobiol J 18:3-19

Beraldi-Campesi H, Hartnett HE, Anbar A, Gordon GW, Garcia-Pichel F (2009) Effect of biological soil crusts on soil elemental concentrations: implications for biogeochemistry and as traceable biosignatures of ancient life on land. Geobiology 7:348-359

Beraldi-Campesi H, Farmer JD, Garica-Pichel F (2011) Evidence for Mesoproterozoic life on land and its modern counterpart in arid soils. Proceedings of the GSA Annual Meeting, Minneapolis, 9-12 October 2011,

Bernard S, Benzerara K, Beyssac O, Menquy N, Guyot F, Brown GE Jr, Goffe B (2007) Exceptional preservation of fossil plant spores in high-pressure metamorphic rocks. Earth Planet Sc Lett 262:257-272

Beukes NJ, Dorland H, Gutzmer J, Nedachi M, Ohmoto H (2002) Tropical laterites, life on land, and the history of atmospheric oxygen in the Paleoproterozoic. Geology 30:491-494

Blackwell M (2000) Terrestrial life: fungal from the start? Science 289(5486):1884-1885

Blank CE (2009) Not so old Archaea-the antiquity of biogeochemical processes in the archaeal domain of life. Geobiology 7(5):495-514

Booth WE (1941) Algae as pioneers in plant succession and their importance in erosion control. Ecology 22:38-46

Bouvier W (2010) The age of the Solar System redefined. Nat Geosci 3:637-641

Boyet M, Carlson RW (2005) ${ }^{142} \mathrm{Nd}$ evidence for early (>4.53 Ga) global differentiation of the silicate Earth. Science 309:576-581

Brady NC, Weil RR (2008) The nature and properties of soils, 14th edn. PearsonPrentice Hall, Upper Saddle River, NJ

Brocks JJ (2011) Millimeter-scale concentration gradients of hydrocarbons in Archean shales: live-oil escape or fingerprint of contamination? Geochim Cosmochim Acta 75(11):3196-3213

Büdel B, Weber B, KuhlM PH, Sultemeyer D, Wessels D (2004) Reshaping of sandstone surfaces by cryptoendolithic cyanobacteria: bioalkalisation causes chemical weathering in arid landscapes. Geobiology 2:261-268

Buick R (2008) When did oxygenic photosynthesis evolve? Philos Trans R Soc Lond B Biol Sci 363(1504):2731-2743

Buick R (2010) Early life: ancient acritarchs. Nature 463(7283):885-886

Buick R, Thornett JR, McNaughton NJ, Smith JB, Barley ME, Savage M (1995) Record of emergent continental crust 3.5 billion years ago in the Pilbara Craton of Australia. Nature 375:574-577

Campbell SE (1979) Soil stabilization by a prokaryotic desert crust: implications for Precambrian land biota. Orig Life 9:335-348

Campbell SE, Seeler J, Golubic S (1989) Desert crust formation and soil stabilization. In: J. Skujins (ed) Uses of microbiological processes in arid lands for desertification control and increased productivity (UNEP). Arid Soil Res Rehab 3:217-228

Canup RM, Righter K (eds) (2000) Origin of the Earth and moon. University of Arizona Press, Tucson, AZ

Catling DC, Zahnle KJ, McKay CP (2001) Biogenic methane, hydrogen escape, and the irreversible oxidation of early Earth. Science 293:839-843

Cavosie AJ, Valley JW, Wilde S (2007) The oldest terrestrial mineral record: a review of 4400 to 3900 Ma detrital zircons from Jack Hills, Western Australia. In: Van Kranendonk MJ, Smithies RH, Bennett V (eds) Earth's oldest rocks. developments in Precambrian geology, Series 15. Elsevier, Amsterdam, pp 91-111

Chanal A, Chapon V, Benzerara K, Barakat M, Christen R, Achouak W, Barras F, Heulin T (2006) The desert of Tataouine: an extreme environment that hosts a wide diversity of microorganisms and radiotolerant bacteria. Environ Microbiol 8(3):514-525

Chen Y, Wu L, Boden R, Hillebrand A, Kumaresan D, Moussard H, Baciu M, Lu Y, Murrell JC (2009) Life without light: microbial diversity and evidence of sulfur- and ammonium-based chemolithotrophy in Movile Cave. ISME J 3:1093-1104

Chenu C, Stotzky G (2002) Interactions between microorganisms and soil particles: an overview. In: Huang PM, Bollag JM, Senesi N (eds) Interactions between soil particles and microorganisms: impact on the terrestrial ecosystem. John Wiley and Sons, Chichester, pp 4-40

Chorover J, Kretzschmar R, Garcia-Pichel F, Sparks DL (2007) Soil biogeochemical processes within the Critical Zone. Elements 3:321-326

Cloud P, Germs A (1971) New pre-paleozoic nannofossils from the Stoer formation (Torridonian), Northwest Scotland. Geol Soc Am Bull 82:3469-3474

Condie KC (2004) Precambrian superplume events. In: Eriksson PG, Altermann W, Nelson DR, Mueller WU, Catuneanu O (eds) The Precambrian Earth: tempos and events. Developments in Precambrian geology, vol. 12. Elsevier, Amsterdam, pp 163-173

Corcoran PL, Mueller WU (2004) Aggressive Archaean weathering. In: Eriksson PG, Altermann W, Nelson DR, Mueller WU, Catuneanu O (eds) The Precambrian 
Earth: tempos and events. Developments in Precambrian geology, vol. 12. Elsevier, Amsterdam, pp 494-504

Dauphas N, van Zuilen M, Wadhwa M, Davis AM, Martey B, Janney PE (2004) Clues from Fe isotope variations on the origin of early Archean BIFs from Greenland. Science 302:2077-2080

David LA, Alm EJ (2011) Rapid evolutionary innovation during an Archaean genetic expansion. Nature 469(7328):93-96

Davison J (1999) Genetic exchange between bacteria in the environment. Plasmid 42(2):73-91

Deming D (2002) Origin of the ocean and continents: a unified theory of the earth. Int Geol Rev 44:137-152

DesMarais DJ (2000) When did photosynthesis emerge on Earth? Science 289:1703-1705

DiMichele WA, Hook RW (1992) Paleozoic terrestrial ecosystems. In: Behrensmeyer AK, Damuth JD, DiMichele WA, Potts R, Suess HD, Wing SL (eds) Terrestrial ecosystems through time. Chicago University Press, Chicago, pp 205-325

Dong GR, Li CZ, Jin T, Gao SY, Wu D (1987) Some results on soil wind-tunnel imitating experiment. Chinese Sci Bull 32:297-301

Dott RH Jr (2003) The importance of eolian abrasion in supermature quartz sandstones and the paradox of weathering on vegetation-free landscapes. $J$ Geol 111:387-405

Driese SG, Gordon-Medaris L Jr (2008) Evidence for biological and hydrological controls on the development of a Paleoproterozoic paleoweathering profile in the Baraboo Range, Wisconsin, USA. J Sediment Res 78:443-457

Driese SG, Simpson EL, Eriksson KA (1995) Redoximorphic paleosols in alluvial and lacustrine deposits, $1.8 \mathrm{Ga}$ lochness formation, Mount Isa, Australia: pedogenic processes and implications for paleoclimate. J Sediment Res A65:675-689

Ehrlich HL (2002) Geomicrobiology. Marcel Dekker, New York, NY

El Albani A, Bengtson S, Canfield DE, Bekker A, Macchiarelli R, Mazurier A, Hammarlund EU, Boulvais P, Dupuy JJ, Fontaine C, Fürsich FT, GauthierLafaye F (2010) Large colonial organisms with coordinated growth in oxygenated environments 2.1 Gyr ago. Nature 466(7302):100-104

Elbert W, Weber B, Burrows S, Steinkamp J, Büdel B, Andreae MO, Pöschl U (2012) Contribution of cryptogamic covers to the global cycles of carbon and nitrogen. Nat Geosci 5:459-462

Engel AS (2010) Microbial diversity of cave ecosystems. In: Barton L, Mandl M, Loy A (eds) Geomicrobiology: molecular and environmental perspectives, Springer, New York, pp 219-238

Eriksson PG, Martins-Neto MA (2004) Commentary. In: The Precambrian Earth: tempos and events. Developments in Precambrian geology, vol. 12. Elsevier, Amsterdam, pp 677-680

Eriksson PG, Simpson EL, Eriksson KA, Bumby AJ, Steyn GL, Sarkar S (2000) Muddy roll-up structures in siliciclastic interdune beds of the c. 1.8 Ga Waterberg Group, South Africa. PALAIOS 15:177-183

Eriksson PG, Altermann W, Nelson DR, Mueller WU, Catuneanu O (2004) The Precambrian Earth: tempos and events. Developments in Precambrian geology, vol. 12. Elsevier, Amsterdam

Farmer J (1999) Taphonomic modes in microbial fossilization. In: Space Studies Board (ed) Size limits of very small microorganisms. National Research Council, National Academy Press, Washington DC, pp 94-102

Farrow CE, Mossman DJ (1988) Geology of Precambrian paleosols at the base of the Huronian supergroup, Elliot Lake, Ontario, Canada. Precambrian Res 42:107-139

Fedo CM, Whitehouse MJ (2002) Metasomatic origin of quartz-pyroxene rock, Akilia, Greenland, and implications for Earth's earliest life. Science 296:1448-1452

Fierer N, Nemergut D, Knight R, Craine JM (2010) Changes through time: integrating microorganisms into the study of succession. Res Microbiol 161:635-642

Fleming ED, Castenholz RW (2007) Effects of periodic desiccation on the synthesis of the UV-screening compound, scytonemin, in cyanobacteria. Environ Microbiol 9:1448-1455

Fletcher JE, Martin WP (1948) Some effects of algae and mold in the rain-crust of desert soils. Ecology 29(1):95-100

Fliegel D, Wirth R, Simonetti A, Furnes $H$, Staudigel H, Hanski E, Muehlenbachs (2010) Septate-tubular textures in 2.0-Ga pillow lavas from the Pechenga Greenstone Belt: a nano-spectroscopic approach to investigate their biogenicity. Geobiology 8:372-390
Franz G, Mosbrugger V, Menge R (1991) Carbo-Permian pteridophyll leaf fragments from an amphibolite facies basement, Tauern Window, Austria. Terra Nova 3:137-141

Friedmann El (1980) Endolithic microbial life in hot and cold deserts. Orig Life 10:223-235

Fritsch FE (1922) The terrestrial alga. J Ecol 10(2):220-236

Furnes H, Banerjee NR, Muehlenbachs K, Staudigel H, de Wit M (2004) Early life recorded in Archean pillow lavas. Science 304:578-81

Furnes H, de Wit M, Staudigel H, Rosing M, Muehlenbachs K (2007a) Vestige of Earth's oldest ophiolite. Science 315:1704-1707

Furnes H, Banerjee NR, Staudigel H, Muehlenbachs K, McLoughlin N, de Wit M, Van Kranendonk M (2007b) Comparing petrographic signatures of bioalteration in recent to Mesoarchean pillow lavas: tracing subsurface life in oceanic igneous rocks. Precambrian Res 158:156-176

Gadd GM (ed) (2006) Fungi in biogeochemical cycles. Cambridge University Press, Cambridge, UK

Gall Q (1994) The Proterozoic Thelon paleosol, Northwest Territories, Canada. Precambrian Res 68:115-137

Gao Q, Garcia-Pichel F (2011) Microbial ultraviolet sunscreens. Nat Rev Microbiol 9:791-802

García Ruiz JM, Carnerup A, Christy AG, Welham NJ, Hyde ST (2002) Morphology: an ambiguous indicator of biogenicity. Astrobiology 2(2):353-369

Garcia-Pichel F (1998) Solar ultraviolet and the evolutionary history of cyanobacteria. Origins Life Evol. Biosphere 28:321-347

Garcia-Pichel F, Castenholz RW (1991) Characterization and biological implications of scytonemin, a cyanobacterial sheath pigment. J Phycol 27:395-409

Garcia-Pichel F, Pringault O (2001) Cyanobacteria track water in desert soils. Nature 413:380-381

Garcia-Pichel F, Wojciechowski MF (2009) The evolution of a capacity to build supra-cellular ropes enabled filamentous cyanobacteria to colonize highly erodible substrates. PLoS One 4(11):e7801

Garcia-Pichel F, Lopez-Cortes A, Nubel U (2001) Phylogenetic and morphological diversity of cyanobacteria in soil desert crusts from the Colorado Plateau. Appl Environ Microbiol 67:1902-1910

Garcia-Pichel F, Belnap J, Neuer S, Schanz F (2003) Estimates of global cyanobacterial biomass and its distribution. Algol Stud 109:213-227

Garcia-Ruiz JM, Hyde ST, Carnerup AM, Christy AG, Van Kranendonk MJ, Welham NJ (2003) Self-assembled silica-carbonate structures and detection of ancient microfossils. Science 302:1194-1197

Gaucher C, Sial AN, Halverson GP, Frimmel HE (2010) Neoproterozoic-Cambrian tectonics, global change and evolution: a focus on Southwestern Gondwana. Developments in Precambrian Geology, vol. 16. Elsevier, Amsterdam

Gay AL, Grandstaff DE (1980) Chemistry and mineralogy of Precambrian paleosols at Elliot Lake, Ontario, Canada. Precambrian Res 12:349-373

Geesey G, Jang L (1990) Extracellular polymers for metal binding. In: Ehrlich HL, Brierley CL (eds) Microbial mineral recovery. McGraw-Hill, New York, pp 223249

Gensel PG (2008) The earliest land plants. Annu Rev Ecol Evol Syst 39:459-477

Ghiorse W, Wilson J (1988) Microbial ecology of the terrestrial subsurface. In: Laskin A (ed) Advances in applied microbiology. Academic, New York, pp 107-172

Giordanino F, Strauch SM, Villafañe VE, Helbling EW (2011) Influence of temperature and UVR on photosynthesis and morphology of four species of cyanobacteria. J Photochem Photobiol B: Biol 103:68-77

Glass JB, Wolfe-Simon F, Anbar AD (2009) Coevolution of metal availability and nitrogen assimilation in cyanobacteria and algae. Geobiology 7:100-123

Glikson A (2007) Early Archean asteroid impacts on Earth: stratigraphic and isotopic age correlations and possible geodynamic consequences. In: Van Kranendonk MJ, Smithies RH, Bennett V (eds) Earth's oldest rocks. Developments in Precambrian geology, Series 15. Elsevier, Amsterdam, pp 1087-1103

Glover JF, Kah LC (2006) Speleothem deposits in a Proterozoic paleokarst, Mesoproterozoic dismal lakes group, Arctic Canada., , Geological Society of America Abstracts with Programs 38(3):36

Gogarten JP, Fournier G, Zhaxybayeva O (2007) Gene transfer and the reconstruction of life's early history from genomic data. In: Botta O, Bada JL, Gomez-Elvira J, Javaux E, Selsis F, Summons R (eds) Strategies of life detection. Space Science Series of ISSI, vol. 25. Springer, New York, pp 115-131 
Golubic S, Campbell SE (1979) Analagous microbial forms in recent subaerial habitats and in Precambrian cherts: Gloethece coerulea Geitler and Eosynechococcus moorei Hoffmann. Precambrian Res 8:201-217

Golubic S, Hofmann HJ (1976) Comparison of modern and mid-Precambrian Entophysalidaceae (Cyanophyta) in stromatolitic algal mats: cell division and degradation. J Paleont 50:1074-1082

Golubic S, Seong-Joo L (1999) Early Cyanobacterial fossil record: preservation, palaeoenvironments and identification. Eur J Phycol 34:339-348

Gomes R, Levison HF, Tsiganis K, Morbidelli A (2005) Origin of the cataclysmic late heavy bombardment period of the terrestrial planets. Nature 435 (7041):466-469

Gradzinski M, Chmiel MJ, Lewandowska A, Michalska-Kasperkiewicz B (2010) Siliciclastic micro-stromatolites in a sandstone cave: role of trapping and binding of detrital particles in formation of cave deposits. Ann Soc Geol Polon 80(3):303-314

Grandstaff DE, Edelman MJ, Foster RW, Zbinden E, Kimberley MM (1986) Chemistry and mineralogy of Precambrian paleosols at the base of the Dominion and Pongola Groups. Precambrian Res 32:97-131

Gray J, Boucot AJ (1994) Early Silurian nonmarine animal remains and the nature of the early continental ecosystem. Acta Palaeontol Polon 38(3-4):303-328

Gray J, Shear WA (1992) Early life on land. Am Sci 80:444-456

Gunatilaka A (1975) Some aspects of the biology and sedimentology of laminated algal mats from Mannar Lagoon, northwest Ceylon. Sediment Geol 14:275-300

Gutzmer J, Beukes NJ (1998) Earliest laterites and possible evidence for terrestrial vegetation in the Early Proterozoic. Geology 26:263-266

Hallbauer DK (1975) The plant origin of the Witwatersrand carbon. Minerals Sci Eng 7(2):111-131

Hallbauer DK, van Warmelo KT (1974) Fossilized plants in thucholite from Precambrian rocks of the Witwatersrand, South Africa. Precambrian Res 1:199-212

Hamblin WK, Christiansen EH (2007) Earth's dynamic systems, 10th edn. Prentice Hall, Upper Saddle River, NJ

Han TM, Runnegar B (1992) Megascopic eukaryotic algae from the 2.1-billionyear-old negaunee iron-formation, Michigan. Science 257(5067):232-235

Hanel M, Montenari M, Kalt A (1999) Determining sedimentation ages of highgrade metamorphic gneisses by their palynological record: a case study in the northern Schwarzwald (Variscan Belt, Germany). Int J Earth Sci 88:49-59

Harrison SP, Kohfeld KE, Roelandt C, Claquin T (2001) The role of dust in climate changes today, at the last glacial maximum and in the future. Earth Sci Rev 54:43-80

Hartmann WK, Ryder G, Dones L, Grinspoon D (2000) The time-dependent intense bombardment of the primordial Earth/Moon system. In: Canup RM, Righter K (eds) Origin of the Earth and moon. University of Arizona Press, Tucson, pp 493-512

Hazen RM, Sverjensky DA (2010) Mineral surfaces, geochemical complexities, and the origins of life. In: Deamer D, Szostak JW (eds) The origins of life, vol 5, 2nd edn. Cold Spring Harbor Laboratory Press, Cold Spring Harbor, pp $1-21$

Hazen RM, Golden J, Downs RT, Hystad G, Grew ES, Azzolini D, Sverjensky DA (2012) Mercury ( $\mathrm{Hg}$ ) mineral evolution: a mineralogical record of supercontinent assembly, changing ocean geochemistry, and the emerging terrestrial biosphere. Am Mineral 97:1013-1042

Heckman DS, Geiser DM, Eidell BR, Stauffer RL, Kardos NL, Hedges SB (2001) Molecular evidence for the early colonization of land by fungi and plants. Science 293(5532):1129-1133

Herrero A, Flores E (eds) (2008) The cyanobacteria: molecular biology, genomics and evolution. Caister Academic Press, Norfolk

Hickman AH, Van Kranendonk MJ (2012) Early Earth evolution: evidence from the 3.5-1.8 Ga geological history of the Pilbara region of Western Australia. Episodes 35(1):283-297

Hoashi M, Bevacqua DC, Otake T, Watanabe Y, Hickman AH, Utsunomiya S, Ohmoto H (2009) Primary haematite formation in an oxygenated sea 3.46 billion years ago. Nat Geosci 2:301-306

Hoffman PF (1995) The oldest terrestrial landscape. Nature 375(6532):537-538

Hoffman PF, Schrag DP (2002) The snowball Earth hypothesis: testing the limits of global change. Terra Nova 14:129-155

Hofmann HJ (1976) Precambrian microflora, Belcher Islands, Canada; significance and systematics. J Paleontol 50:1040-1073

Holland HD (1984) The chemical evolution of the atmosphere and oceans. Princeton University Press, Princeton
Holland HD (1992) Distribution and paleoenvironment interpretation of Proterozoic paleosols. In: Schopf JW, Klein C (eds) The Proterozoic biosphere. Cambridge University Press, Cambridge, pp 153-155

Holm NG (1992) Marine hydrothermal systems and the origins of life. Orig Life Evol Biosph 22:181-242

Hoppert M, Reimer R, Kemmling A, Schröder A, Günzl B, Heinken T (2004) Structure and reactivity of a biological soil crust from a xeric sandy soil in central Europe. Geomicrobiol J 21:183-191

Horodyski RJ, Knauth PL (1994) Life on land in the Precambrian. Science 263 (5146):494-498

Hu C, Liu Y, Song L, Zhang D (2002) Effect of desert soil algae on the stabilization of fine sands. J Appl Phycol 14(4):281-292

Hupe P (1952) Sur des problematica du Precambrien III. Division des Mines et de la Géologie, Service Géologique de Morocco, Notes et Memoires 103:297-383

lizuka T, Horie K, Komiya T, Maruyama S, Hirata T, Hidaka H, Windley BF (2006) 4.2 Ga zircon xenocryst in an Acasta gneiss from northwestern Canada: evidence for early continental crust. Geology 34:245-248

Ishizuka H (2008) Protoliths of the Napier Complex in Enderby Land, East Antarctica; an overview and implication for crustal formation of Archean continents. J Miner Petrol Sci 103:218-225

Jackson TA (1967) Fossil Actinomycetes in Middle Precambrian glacial varves. Science, New Series 155(3765):1003-1005

Javaux EJ, Marshall CP, Bekker A (2010) Organic-walled microfossils in 3.2-billionyear-old shallow-marine siliciclastic deposits. Nature 463:934-938

Jickells TD, An ZS, Andersen KK, Baker AR, Bergametti G, Brooks N, Cao JJ, Boyd PW, Duce RA, Hunter KA, Kawahata H, Kubilay N, laRoche J, Liss PS, Mahowald N, Prospero JM, Ridgwell AJ, Tegen I, Torres R (2005) Global iron connections between desert dust, ocean biogeochemistry, and climate. Science 308:67-71

Johnson I, Watanabe Y, Stewart B, Ohmoto H (2009) Earth's oldest ( 3.4 Ga) lateritic paleosol in the Pilbara Craton, Western Australia. Proceedings of the Goldschmidt conference, Davos, Switzerland

Johnson I, Watanabe Y, Stewart B, Ohmoto H (2010) Evidence for terrestrial life and an O2-rich atmosphere in the oldest $(\sim 3.4 \mathrm{Ga})$ paleosol in the east Pilbara craton, Western Australia. Proceedings of the 6th Astrobiology Science Conference, League City, TX, 20-26 April 2010

Kandler O (1994) The early diversification of life. In: Bengston S (ed) Early life on earth. Columbia University Press, New York, pp 152-161

Kappler A, Pasquero C, Konhauser KO, Newman DK (2005) Deposition of banded iron formations by anoxygenic phototrophic Fe(II)-oxidizing bacteria. Geology 33(11):865-868

Kasting J (2009) How to find a habitable planet. Princeton University Press, Princeton

Kato Y, Suzuki K, Nakamura K, Hickman AH, Nedachi M, Kusakabe M, Bevacqua DC, Ohmoto H (2009) Hematite formation by oxygenated groundwater more than 2.76 billion years ago. Earth Planet Sci Lett 278:40-49

Keller CK, Wood BD (1993) Possibility of chemical weathering before the advent of vascular land plants. Nature 364:223-225

Kendall B, Reinhard CT, Lyons TW, Kaufman AJ, Poulton SW, Anbar AD (2010) Pervasive oxygenation along late Archaean ocean margins. Nat Geosci 3 (9):647-652

Kennedy MJ, Wagner T (2011) Clay mineral continental amplifier for marine carbon sequestration in a greenhouse ocean. Proc Nat Acad Sci USA 108:9776-9781

Kennedy MJ, Chadwick OA, Vitousek PM, Derry LA, Hendricks DM (1998) Replacement of weathering with atmospheric sources of base cations during ecosystem development, Hawaiian Islands. Geology 26:1015-1018

Kennedy M, Droser M, Mayer LM, Pevear D, Mrofka D (2006) Late Precambrian oxygenation; inception of the clay mineral factory. Science 311:1446-1449

Kimberley MM, Grandstaff DE (1986) Profiles of elemental concentrations in Precambrian paleosols on basaltic and granitic parent materials. Precambrian Res 32:133-154

Kirschvink JL, Kopp RE (2008) Palaeoproterozoic ice houses and the evolution of oxygen-mediating enzymes: the case for a late origin of photosystem II. Phil Trans R Soc B 363:2755-2765

Klein C, Beukes NJ, Schopf JW (1987) Filamentous microfossils in the early Proterozoic Transvaal supergroup: their morphology, significance, and paleoenvironmental setting. Precambrian Res 36:81-94

Knauth LP, Kennedy MJ (2009) The late Precambrian greening of the Earth. Nature 460:728-732 
Knoll AH, Javaux EJ, Hewitt D, Cohen P (2006) Eukaryotic organisms in Proterozoic oceans. Philosophical Transactions of the Royal Society B 361 (1470):1023-1038

Knoll A, Canfield D, Konhauser K (eds) (2012) Fundamentals of geobiology. Wiley-Blackwell, Chichester

Koehler I, Konhauser KO, Kappler A (2010) Role of microorganisms in banded iron formations. In: Barton L, Mandl M, Loy A (eds) Geomicrobiology: molecular and environmental perspective. Springer, New York, pp 309-324

Komiya T, Maruyama S, Nohda S, Masuda T, Hayashi M, Okamoto S (1999) Plate tectonics at 3.8-3.7 Ga; field evidence from the Isua accretionary complex, southern West Greenland. J Geol 107:515-554

Konhauser K (2007) Introduction to geomicrobiology. Blackwell, Oxford

Konhauser KO, Schultzelam S, Ferris FG, Fyfe WS, Longstaffe FJ, Beveridge TJ (1994) Mineral precipitation by epilithic biofilms in the Speed River, Ontario, Canada. Appl Environ Microbiol 60:549-553

Konhauser KO, Newman DK, Kappler A (2005) The potential significance of microbial Fe(III) reduction during deposition of Precambrian banded iron formations. Geobiology 3:167-177

Kositcin N, Krapez B (2004) SHRIMP U-Pb detrital zircon geochronology of the late Archean Witwatersrand Basin, relation between zircon provenance age spectra and basin evolution. Precambrian Res 129:141-168

Labandeira CC (2005) Invasion of the continents: cyanobacterial crusts to treeinhabiting arthropods. Trends Ecol Evol 20(5):253-262

Lalonde K, Mucci A, Ouellet A, Gélinas Y (2012) Preservation of organic matter in sediments promoted by iron. Nature 483(7388):198-200

Lannerbro R (1954) Description of some structures, possibly fossils, in Jotnian sandstone from Mångsbodarna in Dalecarlia. Geologiska Föreningens i Stockholm Förhandlingar 76:46-50

Lau KM, Kim MK, Kim KM (2006) Asian monsoon anomalies induced by aerosol direct effects. Clim Dyn 26:855-864

Lazcano A, Miller SL (1994) How long did it take for life to begin and evolve to cyanobacteria? J Mol Evol 39:546-554

Li W, Johnson CM, Beard BL (2012) U-Th-Pb isotope data indicate Phanerozoic age for oxidation of the $3.4 \mathrm{Ga}$ Apex Basalt. Earth Planet Sci Lett 319-320:197-206

Liu YZ, Dong GR, Li CZ (1994) A study on the factors influencing soil erosion through wind tunnel experiments. Chin J Arid Land Res 7:359-367

Lopez-Garcia P, Moreira D, Douzery EJP, Forterre P, van Zuilen M et al (2006) Ancient fossil record and early evolution (ca. 3.8 to $0.5 \mathrm{Ga}$ ). In: Gargaud M (ed) From suns to life: a multidisciplinary approach to the history of life on Earth. Earth, moon, and planets. Springer, New York, pp 247-290

Lowe DR (1980) Stromatolites 3,400-Myr old from the Archean of Western Australia. Nature 284:441-443

Lozupone CA, Knight R (2007) Global patterns in bacterial diversity. Proc Natl Acad Sci USA 104:11436-11440

Macfarlane AW, Danielson A, Holland HD (1994) Geology and major and trace element chemistry of the late Archean weathering profiles in the Fortescue Group, Western Australia: implications for atmospheric $\mathrm{pO}_{2}$. Precam Res 65:297-317

Madigan MT, Marrs BL (1997) Extremophiles. Scientific American 276(4):66-71

Madigan M, Martinko J, Parker J (2003) Brock: biology of microorganisms, 10th edn. Pearson-Prentice Hall, Upper Saddle River, NJ

Malam Issa O, Le Bissonnais Y, Défarge C, Trichet J (2001) Role of a cyanobacterial cover on structural stability of sandy soils in the Sahalian part of western Niger. Geoderma 101:15-30

Martini JEJ (1994) A late Archaean-Palaeoproterozoic (2.6 Ga) palaeosol on ultramafics in the eastern Transvaal, South Africa. Precambrian Res 67:159-180

Mazor G, Kidron GJ, Vonshak A, Abeliovich A (1996) The role of cyanobacterial exopolysaccharides in structuring desert microbial crusts. FEMS Microbiol Ecol 21:121-130

McConnell RL (1974) Preliminary report of microstructures of probable biologic origin from the Mescal Formation (Proterozoic) of central Arizona. Precambrian Res 1(3):227-234

McKeegan KD, Kudryavtsev AB, Schopf JW (2007) Raman and ion microscopic imagery of graphitic inclusions in apatite from older than 3830 Ma Akilia supracrustal rocks, west Greenland. Geology 35:591-594

McTainsh GH, Strong CL (2007) The role of aeolian dust in ecosystems. Geomorphology 89(1-2):39-54

Meadow JF, Zabinski CA (2012) Spatial heterogeneity of eukaryotic microbial communities in an unstudied geothermal diatomaceous biological soil crust: Yellowstone National Park, WY, USA. FEMS Microbiol Ecol 82(1):182-191
Mloszewska AM, Pecoits E, Cates NL, Mojzsis SJ, O'Neil J, Robbins LJ, Konhauser KO (2012) The composition of Earth's oldest iron formations: the Nurvuagittuq Supracrustal Belt (Quebec, Canada). Earth Planet Sci Lett 317-318:331-342

Mojzsis SJ, Harrison MT, Pidgeon RT (2001) Oxygen-isotope evidence from ancient zircons for liquid water at the Earth's surface 4,300 Myr ago. Nature 409:178-181

Mossman DJ, Minter WEL, Dutkiewicz A, Hallbauer DK, George SC, Hennigh Q, Reimer TO, Horscroft FD (2008) The indigenous origin of Witwatersrand "carbon". Precambrian Res 164:173-186

Mulkidjanian AY, Bychkovc AY, Dibrova DV, Galperin MY, Koonin EV (2012) Origin of the first cells at terrestrial, anoxic geothermal fields. Proc Natl Acad Sci USA 109:E821-E830

Myers JS (2001) Protoliths of the 3.8-3.7 Ga Isua Greenstone Belt, West Greenland. Precambrian Res 105:129-141

Myers JS (2004) Isua enigmas: illusive tectonic, sedimentary, volcanic and organic features of the $>3.7 \mathrm{Ga}$ Isua greenstone belt, southwest Greenland. In: Eriksson PG, Altermann W, Nelson DR, Mueller WU, Catuneanu O (eds) The Precambrian Earth: tempos and events. Developments in Precambrian geology, vol. 12. Elsevier, Amsterdam, pp 66-73

Nagy M, Perez A, Garcia-Pichel F (2005) The prokaryotic diversity of biological soil crusts in the Sonoran desert (Organ Pipe Cactus National Monument, AZ). FEMS Microbiol Ecol 54:233-245

Neher DA, Lewins SA, Weicht TR, Darby BJ (2009) Microarthropod communities associated with biological soil crusts in the Colorado Plateau and Chihuahuan deserts. J Arid Environ 73:672-677

Nelson DR (2004) Earth's formation and first billion years. In: Eriksson PG, Altermann W, Nelson DR, Mueller WU, Catuneanu O (eds) The Precambrian Earth: tempos and events, $\backslash$. Developments in Precambrian geology, vol. 12. Elsevier, Amsterdam, pp 3-27

Nemergut DR, Costello EK, Hamady M, Lozupone C, Jiang L, Schmidt SK, Fierer N, Townsend AR, Cleveland CC, Stanish L, Knight R (2011) Global patterns in the biogeography of bacterial taxa. Environ Microbiol 13(1):135-144

Nesbitt HW, Young GM (2004) Aggressive Archaean weathering. In: Eriksson PG, Altermann W, Nelson DR, Mueller WU, Catuneanu O (eds) The Precambrian Earth: tempos and events. Developments in Precambrian geology, vol. 12. Elsevier, Amsterdam, pp 482-493

Nicholas J, Bildgen P (1979) Relations between the location of the karst bauxites in the northern hemisphere, the global tectonics, and the climatic variations during geological time. Palaeogeogr Palaeoclimateol Palaeoecol 28:205-239

Noffke N (2010) Geobiology: microbial mats in sandy deposits from the Archean era to today. Springer, Berlin

Noffke N (2011) A Modern Perspective on Ancient Life: Microbial Mats in Sandy Marine Settings from the Archean Era to Today. In: Golding SD, Glikson M (eds) Earliest Life on Earth: Habitats. Environments and Methods of Detection. Springer, Dordrecht, pp 171-182

Noffke N, Gerdes G, Klenke T, Krumbein WE (2001) Perspectives. Microbially induced sedimentary structures - a new category within the classification of primary sedimentary structures. J Sediment Res 71(5):649-656

Noffke N, Eriksson KA, Hazen RM, Simpson EL (2006) A new window into Early Archean life: microbial mats in Earth's oldest siliciclastic tidal deposits (3.2 Ga Moodies Group, South Africa). Geology 34(4):253-256

Noffke N, Beukes N, Bower D, Hazen RM, Swift DJP (2008) An actualistic perspective into Archean worlds - (cyano-)bacterially induced sedimentary structures in the siliciclastic Nhlazatse Section, 2.9 Ga Pongola Supergroup, South Africa. Geobiology 6:5-20

Noffke N, Christian DR, Hazen RM (2011) A (cyano-)bacterial ecosystem in the Archean 3.49 Ga Dresser Formation, Pilbara, Western Australia. GSA Annual Meeting in Minneapolis. Paper No. 56-11. Geological Society of America Abstracts with Programs 43(5):159

Nutman AP (2006) Antiquity of the oceans and continents. Elements 2:223-227

Nutman AP, McGregor VR, Friend CRL, Bennett VC, Kinny PD (1996) The Itsaq Gneiss Complex of southern West Greenland; the world's most extensive record of early crustal evolution (3900-3600 Ma). Precambrian Res 78:1-39

Nutman AP, Friend CRL, Bennett VC (2002) Evidence for 3650-3600 Ma assembly of the northern end of the Itsaq Gneiss Complex, Greenland: implication for early Archaean tectonics. Tectonics 21(1):5-1-5-28

Nutman AP, Friend CRL, Bennett VC, Wright D, Norman MD (2010) $\geq 3700 \mathrm{Ma}$ pre-metamorphic dolomite formed by microbial mediation in the Isua supracrustal belt (W. Greenland): simple evidence for early life? Precambrian Res 183:725-737 
O'Neil J, Francis D, Carlson RW (2011) Implications of the Nuvvuagittuq greenstone belt for the formation of earth's early crust. J Petrol 52:985-1009

Och LM, Shields-Zhou GA (2012) The Neoproterozoic oxygenation event. Environmental perturbations and biogeochemical cycling. Earth Sci Rev 110 $(1-4): 26-57$

Ohmoto H (1996) Evidence in pre-2.2 Gapaleosols for the early evolution of atmospheric oxygen and terrestrial biota. Geology 24:1135-1138

Ohmoto H (2004) Archean atmosphere, hydrosphere, and biosphere. In: Eriksson PG, Altermann W, Nelson DR, Mueller WU, Catuneanu O (eds) The Precambrian Earth: tempos and events. Developments in Precambrian geology, vol. 12. Elsevier, Amsterdam, pp 361-368

Ohmoto H, Watanabe Y, Allwood A, Burch I, Knauth P, Yamaguchi K, Johnson I, Altinok E (2007) Formation of probable lateritic soils $\sim 3.43 \mathrm{Ga}$ in the Pilbara Craton, Western Australia. Geochimica et Cosmochimica Acta, Supplement 71(15):A733

Omelon CR, Pollard WH, Ferris FG (2006) Chemical and ultrastructural characterization of high arctic cryptoendolithic habitats. Geomicrobiol J 23:189-200

O'Neil J, Carlson RW, Francis D, Stevenson RK (2009) Response to comment on "Neodymium-142 evidence for Hadean mafic crust". Science 325:267b

Pace N (1997) A molecular view of microbial diversity and the biosphere. Science 276:734-740

Palmer JA, Phillips GN, McCarthy TS (1989) Paleosols and their relevance to Precambrian atmospheric composition. J Geol 97:77-92

Pandit MK, de Wall H, Chauhan NK (2008) Paleosol at the Archean-Proterozoic contact in NW India revisited: evidence for oxidizing conditions during paleo-weathering? J Earth Syst Sci 117(3):201-209

Papineau D, DeGregorio BT, Cody GD, Fries MD, Mojzsis SJ, Steele A, Stroud RM, Fogel ML (2010a) Ancient graphite in the Eoarchean quartz-pyroxene rock from Akilia in southwest Greenland I: petrographic and spectroscopic characterization. Geochim Cosmochim Acta 74:5862-5883

Papineau D, DeGregorio BT, Stroud RM, Steele A, Pecoits E, Konhauser K, Wang J, Fogel ML (2010b) Ancient graphite in the Eoarchean quartz-pyroxene rock from Akilia in southern West Greenland II: isotopic and chemical compositions and comparison with Paleoproterozoic banded iron formations. Geochim Cosmochim Acta 74:5884-5905

Papineau D, De Gregorio BT, Cody GD, O'Neil J, Steele A, Stroud RM, Fogel ML (2011) Young poorly crystalline graphite in the 3.8-Gyr-old Nuvvuagittuq banded iron formation. Nat Geosci 4(6):376-379

Paul EA, Collins HP, Leavitt SW (2001) Dynamics of resistant soil carbon of Midwestern agricultural soils measured by naturally occurring ${ }^{14} \mathrm{C}$ abundance. Geoderma 104(3-4):239-256

Porter ML, Engel AS, Kinkle B, Kane TC (2009) Productivity-diversity relationships from chemolithoautotrophically based sulfidic karst systems. Int I Speleol 38:27-40

Potts M (1999) Mechanisms of desiccation tolerance in cyanobacteria. Eur J Phycol 34:319-328

Potts M, Friedmann El (1981) Effects of water stress on cryptoendolithic cyanobacteria from hot desert rocks. Arch Microbiol 130:267-271

Prasad N, Roscoe SM (1996) Evidence of anoxic to oxic atmospheric change during 2.45-2.22 Ga from lower and upper sub-Huronian paleosols, Canada. Catena 27:105-121

Prave AR (2002) Life on land in the Proterozoic: evidence from the Torridonian rocks of northwest Scotland. Geology 30(9):811-814

Pufahl PK, Hiatt EE (2012) Oxygenation of the Earth's atmosphere-ocean system: a review of physical and chemical sedimentologic responses. J Mar Petrol Geol 32(1):1-20

Rasmussen B (2000) Filamentous microfossils in a 3,235-million-year-old volcanogenic massive sulphide deposit. Nature 405:676-679

Rasmussen B, Fletcher IR, Brocks JJ, Kilburn MR (2008) Reassessing the first appearance of eukaryotes and cyanobacteria. Nature 455(7216):1101-1104

Rasmussen B, Blake TS, Fletcher IR, Kilburn MR (2009) Evidence for microbial life in synsedimentary cavities from $2.75 \mathrm{Ga}$ terrestrial environments. Geology 37:423-426

Reddy SG, Garcia-Pichel F (2006) The community and phylogenetic diversity of biological soil crusts in the Colorado Plateau studied by molecular fingerprinting and intensive cultivation. Microb Ecol 52:345-357

Reimer TO (1986) Alumina-rich rocks from the Early Precambrian of the Kaapvaal craton as indicators of paleosols and as products of other decompositional reactions. Precambrian Res 32:155-179

Retallack GJ (1986a) The fossil record of soils. In: Wright PV (ed) Paleosols: their recognition and interpretation. Blackwell, Oxford, pp 1-57
Retallack GJ (1986b) Reappraisal of a 2200 Ma-old paleosol near Waterval Onder, South Africa. Precambrian Res 32:195-232

Retallack GJ (2001) Soils of the past, 2nd edn. Blackwell Science, London

Retallack GJ (2009) Cambrian-Ordovician non-marine fossils from South Australia. Alcheringa 33:355-391

Retallack (2011) Criteria for distinguishing microbial mats and earths. In: Noffke N, Chafetz H (ed) Microbial mats in siliciclastic depositional systems through time. SEPM Special Publication no. 101. Society for Sedimentary Geology, Tulsa, OK, pp 139-152

Retallack GJ (2013) Ediacaran life on land. Nature 493(7430):89-92

Retallack GJ, Mindszenty A (1994) Well preserved Late Precambrian paleosols from northwest Scotland. J Sediment Res A64:264-281

Reynolds R, Belnap J, Reheis M, Lamothe P, Luiszer F (2001) Aeolian dust in Colorado Plateau soils: nutrient inputs and recent change in source. Proc Natl Acad Sci USA 98:7123-7127

Rino S, Komiya T, Windley BF, Katayama S, Motoki A, Hirata T (2004) Major episodic increases of continental crust growth determined from zircon ages of river sands; implication for mantle overturns in the early Precambrian. Phys Earth Planet Inter 146:369-394

Romans BW, Graham SA (2013) A deep-time perspective of land-ocean linkages in the sedimentary record. Annu Rev Mar Sci 5:69-94

Rosing MT, Frei R (2004) U-rich Archaean sea-floor sediments from Greenland: indications of > $3700 \mathrm{Ma}$ oxygenic photosynthesis. Earth Planet Sc Lett 217:237-244

Rosing MT, Bird DK, Sleep NH, Glassley W, Albarede F (2006) The rise of continents - an essay on the geologic consequences of photosynthesis. Palaeogeogr Palaeoclimateol Palaeoecol 232:99-113

Rossi F, Potrafka RM, Garcia-Pichel F, De Philippis R (2012) The role of the exopolysaccharides in enhancing hydraulic conductivity of biological soil crusts. Soil Biol Biochem 46:33-40

Rye R, Holland HD (2000) Life associated with a $2.76 \mathrm{Ga}$ ephemeral pond? Evidence from Mount Roe \#2 paleosol. Geology 28:483-486

Santosh M (2010) A synopsis of recent conceptual models on supercontinent tectonics in relation to mantle dynamics, life evolution and surface environment. J Geodyn 50(3-4):116-133

Sarbu SM, Kane TC, Kinkle BK (1996) A chemoautotrophically based cave ecosystem. Science 272:1953-1955

Schau M, Henderson JB (1983) Archean chemical weathering at three localities on the Canadian shield. Dev Precambrian Geol 7:81-116

Schieber J, Bose PK, Eriksson PG, Banerjee S, Sarkar S, Altermann W, Catuneau O (eds) (2007) Atlas of microbial mat features preserved within the siliclastic rock record. Elsevier, Amsterdam

Schiffbauer JD, Xiao S (2009) Novel application of focused ion beam-electron microscopy (FIB-EM) in preparation and analysis of microfossils ultrastructures: a new view of complexity in early eukaryotic organisms. Palaios 24:616-626

Schiffbauer JD, Yin L, Bodnar RJ, Kaufman AJ, Meng F, Hu J, Shen B, Yuan X, Bao $H$, Xiao S (2007) Ultrastructural and geochemical characterization of ArcheanPaleoproterozoic graphite particles: implications for recognizing traces of life in highly metamorphosed rocks. Astrobiology 7:684-704

Schiffbauer JD, Wallace AF, Hunter JL Jr, Kowalewski M, Bodnar RJ, Xiao S (2012) Thermally-induced structural and chemical alteration of organic-walled microfossils: an experimental approach to understanding fossil preservation in metasediments. Geobiology 10(5):402-423

Schirrmeister BE, de Vosb JM, Antonelli A, Bagheri HC (2013) Evolution of multicellularity coincided with increased diversification of cyanobacteria and the Great Oxidation Event. PNAS-USA: doi:10.1073/pnas.1209927110

Schmidt SK, Reed SC, Nemergut DR, Stuart-Grandy A, Cleveland CC, Weintraub MN, Hill AW, Costello EK, Meyer AF, Neff JC, Martin AM (2008) The earliest stages of ecosystem succession in high-elevation (5000 metres above sea level), recently deglaciated soils. Proc Biol Sci 275 (1653):2793-2802

Schopf JW (1968) Microflora of the bitter springs formation, late Precambrian, central Australia. J Paleontol 42:651-688

Schopf JW (ed) (1983) Earth's earliest biosphere. Princeton University Press, Princeton, $\mathrm{NJ}$

Schopf JW (1992a) Paleobiology of the Archean. In: Schopf JW, Klein C (eds) The Proterozoic biosphere. Cambridge University Press, New York

Schopf JW (1992b) Proterozoic prokaryotes: affinities, geologic distribution, and evolutionary trends. In: Schopf JW, Klein C (eds) The Proterozoic biosphere. Cambridge University Press, New York 
Schopf JW, Klein C (eds) (1992) The Proterozoic biosphere. Cambridge University Press, New York

Schopf JW, Walter MR, Ruiji C (2007) Earliest evidence of life on earth. Precambrian Res 158:139-140

Schwartzman DW, Volk T (1989) Biotic enhancement of weathering and the habitability of earth. Nature 340:457-460

Shear WA (1991) The early development of terrestrial ecosystems. Nature 351:283-289

Sheldon ND (2012) Microbially induced sedimentary structures in the ca. $1100 \mathrm{Ma}$ terrestrial midcontinent rift of North America. In: Noffke N, Chafetz H (eds) Microbial mats in siliciclastic depositional systems through time. SEPM Special Publication no. 101. Society for Sedimentary Geology, Tulsa, OK, pp 153-162

Shen Y, Buick R (2004) The antiquity of microbial sulfate reduction. Earth Sci Rev $64: 243-272$

Shen Y, Farquhar J, Masterson A, Kaufman AJ, Buick R (2009) Evaluating the role of microbial sulfate reduction in the early Archean using quadruple isotope systematics. Earth Planet Sc Lett 279:383-391

Shephard KL (1987) Evaporation of water from the mucilage of a gelatinous algal community. Br Phycol J 22:181-185

Sigler WV, Crivii S, Zeyer J (2002) Bacterial succession in glacial forefield soils characterized by community structure, activity and opportunistic growth dynamics. Microb Ecol 44:306-316

Simpson WS, Simpson EL, Wizevich MC, Malenda HF, Hilbert-Wolf HL, Tindall SE (2010) A preserved Late Cretaceous biological soil crust in the capping sandstone member, Wahweap Formation, Grand Staircase-Escalante National Monument, Utah, Palaeoclimatic implications. Sediment Geol 230:139-145

Singh SP, Kumari S, Rastogi RP, Singh KL, Richa SRP (2010) Photoprotective and biotechnological potentials of cyanobacterial sheath pigment, scytonemin. Afr J Biotechnol 9:580-588

Sinha RP, Häder DP (2002) UV-induced DNA damage and repair: a review. Photochem Photobiol Sci 1:225-236

Skotnicki SJ, Knauth LP (2007) The Middle Proterozoic Mescal Paleokarst, Central Arizona, USA: karst development, silicification, and cave deposits. J Sediment Res 77(12):1046-1062

Sleep NH, Bird DK (2007) Niches of the pre-photosynthetic biosphere and geologic preservation of Earth's earliest ecology. Geobiology 5:101-117

Smith SE, Read D (2008) Mycorrhizal symbiosis, 3rd edn. Elsevier, New York

Squire RJ, Stewart IR, Zang WL (2006) Acritarchs in polydeformed and highly altered Cambrian rocks in western Victoria. Aust J Earth Sci 53:697-705

Stern RJ, Scholl DW (2010) Yin and yang of continental crust creation and destruction by plate tectonic processes. Int Geol Rev 52:1-31

Strother PK, Battison L, Brasier MD, Wellman CH (2011) Earth's earliest non-marine eukaryotes. Nature 473:505-509

Stüeken EE, Catling DC, Buick R (2012) Contributions to late Archaean sulphur cycling by life on land. Nat Geosci 5:722-725

Summons RE, Jahnke LL, Hope JM, Logan GA (1999) 2-Methylhopanoids as biomarkers for cyanobacterial oxygenic photosynthesis. Nature 400:554-557

Sun HJ, Friedmann El (1999) Growth on geological time scales in the Antarctic cryptoendolithic microbial community. Geomicrobiol J 16:193-202

Takeuchi N, Kohshima S, Seko K (2001) Structure, formation, darkening process of albedo reducing material (cryoconite) on a Himalayan glacier: a granular algal mat growing on the glacier. Arct Antarct Alp Res 33:115-122

Taylor TN, Taylor EL, Krings M (2009) Paleobotany: the biology and evolution of fossil plants, 2nd edn. Elsevier, Amsterdam

Thiry M, Simon-Coincon R (eds) (1999) Palaeoweathering, palaeosurfaces and related continental deposits. Special publication 27 of the International Association of Sedimentologists. Blackwell Science, Oxford

Tice MM, Lowe DR (2004) Photosynthetic microbial mats in the 3,416-Myr-old ocean. Nature 431:549-552

Tirkey J, Adhikary SP (2005) Cyanobacteria in the biological soil crusts of India. Curr Sci 89:515-521

Tomitani A, Knoll AH, Cavanaugh CM, Ohno T (2006) The evolutionary diversification of cyanobacteria: molecular-phylogenetic and paleontological perspectives. Proc Natl Acad Sci USA 103:5442-5447

Trendall AF, Blockley JG (2004) Precambrian iron-formations. In: Eriksson PG, Altermann W, Nelson DR, Mueller WU, Catuneanu O (eds) The Precambrian Earth: tempos and events. Developments in Precambrian geology, vol. 12 Elsevier, Amsterdam, pp 403-420

Ueno Y, Yamada K, Yoshida N, Maruyama S, Isozaki Y (2006) Evidence from fluid inclusions for microbial methanogenesis in the early Archaean era. Nature 440:516-519
Van Kranendonk MJ (2004) Archaean tectonics 2004: a review. Precambrian Res 131:143-151

Van Kranendonk MJ (2011) Stromatolite morphology as an indicator of biogenicity for Earth's oldest fossils from the 3.5-3.4 Ga Pilbara Craton Western Australia. In: Reitner J, Queric NV, Arp G (eds) Advances in stromatolite geobiology. Lecture Notes in Earth Sciences, vol. 131. Springer, Germany

Van Kranendonk MJ, Smithies RH, Bennett V (eds) (2007a) Earth's oldest rocks. Developments in Precambrian geology, series 15. Elsevier, Amsterdam

Van Kranendonk MJ, Smithies RH, Hickman AH, Champion DC (2007b) Review: secular tectonic evolution of Archean continental crust: interplay between horizontal and vertical processes in the formation of the Pilbara Craton, Australia. Terra Nova 19(1):1-38

Van Kranendonk MJ, Philippot P, Lepot K, Bodorkos S, Pirajno F (2008) Geological setting of Earth's oldest fossils in the C. 3.5 Ga Dresser Formation, Pilbara Craton, Western Australia. Precambrian Res 167:93-124

van Zuilen MA, Lepland A, Arrhenius G (2002) Reassessing the evidence for the earliest traces of life. Nature 418:627-630

Voigt E (1972) Tonrollen als potentielle Pseudofossilien. Nat Mus 102(11):401-410

Wacey D, Kilburn MR, Saunders M, Cliff J, Brasier MD (2011) Microfossils of sulphur-metabolizing cells in 3.4-billion-year-old rocks of Western Australia. Nat Geosci 4:698-702

Walsh MM (1992) Microfossils and possible microfossils from the Early Archean Onverwacht Group, Barberton Mountain Land, South Africa. Precambrian Res 54:271-292

Walsh MM, Lowe DR (1985) Filamentous microfossils from the 3500 Myr-old Onverwacht Group, Barberton Mountain Land, South Africa. Nature 314:530-532

Walsh MM, Lowe DR (1999) Modes of accumulation of carbonaceous matter in the early Archaean: A petrographic and geochemical study of the carbonaceous cherts of the Swaziland Supergroup. In: Lowe DR, Byerly GR (eds) Geologic Evolution of the Barberton Greenstone Belt, South Africa, Geological Society of America Special Paper 329., pp 115-132

Walter MR (1983) Archean stromatolites: evidence of the Earth's earliest benthos. In: Schopf JW (ed) Earth's earliest biosphere. Princeton University Press, Princeton, pp 187-213

Walter MR, Buick R, Dunlop JSR (1980) Stromatolites 3,400-3,500 Myr old from the North Pole area, Western Australia. Nature 284:443-445

Watanabe Y, Martini JEJ, Ohmoto H (2000) Geochemical evidence for terrestrial ecosystems 2.6 billion years ago. Nature 408:574-578

Welch SA, Barker WW, Banfield JF (1999) Microbial extracellular polysaccharides and plagioclase dissolution. Geochim Cosmochim Acta 63:1405-1419

Westall F (2010) Early life: nature, distribution and evolution. In: Gargaud M, LópezGarcia P. Martin H (eds) Origins and evolution of life. An astrobiological perspective. Cambridge University Press, Cambridge, pp 391-413

Westall F, De Wit MJ, Dann J, Van Der Gaast S, De Ronde C, Gerneke D (2001) Early Archaean fossil bacteria and biofilms in hydrothermally influenced, shallow water sediments, Barberton Greenstone Belt, South Africa. Precambrian Res 106:91-112

Westall F, de Vries ST, Nijman W, Rouchon V, Orberger B, Pearson V, Watson J, Verchovsky A, Wright I, Rouzaud JN, Marchesini D, Anne S (2006a) The 3.466 Ga Kitty's Gap Chert, an Early Archaean microbial ecosystem. In: Reimold WU, Gibson R (eds) Processes on the early Earth. Geological Society of America special paper 405. Geological Society of America, Boulder, CO, pp 105-131

Westall F, de Ronde CEJ, Southam G, Grassineau N, Colas M, Cockell C, Lammer H (2006b) Implications of a 3.472-3.333 Ga-old subaerial microbial mat from the Barberton Greenstone Belt, South Africa for the UV environmental conditions on the early Earth. Phil Trans R Soc B 361:1857-1875

Westall F, Cavalazzi B, Lemelle L, Marrocchi Y, Rouzaud JN, Simionovici A, Salomé M, Mostefaoui S, Andreazza C, Foucher F, Toporski J, Jauss A, Thiel V, Southam G, MacLean L, Wirick S, Hofmann A, Meibom A, Robert F, Défarge C (2011) Implications of in situ calcification for photosynthesis in a $3.3 \mathrm{Ga}$-old microbial biofilm from the Barberton greenstone belt, South Africa. Earth Planet Sci Lett 310(3-4):468-479

White D (2000) The physiology and biochemistry of prokaryotes, 2nd edn. Oxford University Press, Oxford

Whitton BA, Potts M (2000) The ecology of cyanobacteria: their diversity in time and space. Kluwer, Dordrecht

Wilde SA, Valley JW, Peck WH, Graham CM (2001) Evidence from detrital zircons for the existence of continental crust and oceans on the Earth $4.4 \mathrm{Gyr}$ ago. Nature 409:175-178 
Williams JD, Dobrowolsk JP, West NE, Gillette DA (1995) Microphytic crust influence on wind erosion. Trans ASAE 38:131-137

Williams AJ, Buck BJ, Beyene MA (2012) Biological soil crusts in the Mojave Desert, USA: micromorphology and pedogenesis. Soil Sci Soc Am J 76 (5):1685-1695

Windley B (2007) Overview and history of investigation of early Earth rocks. In: Van Kranendonk MJ, Smithies RH, Bennett V (eds) Earth's oldest rocks. Developments in Precambrian geology, series 15. Elsevier, Amsterdam, pp 3-7

Wright VP (1985) The precursor environment for vascular plant colonization. Phil Trans R Soc London B 309:143-145

Xiao S, Kaufman AJ (eds) (2006) Neoproterozoic geobiology and paleobiology Topics in Geobiology, vol. 27. Springer, Dordrecht

Xiao S, Knauth LP (2013) Palaeontology: fossils come in to land. Nature 493 (7430):28-29

Xiong J, Fischer WM, Inoue K, Nakahara M, Bauer CE (2000) Molecular evidence for the early evolution of photosynthesis. Science 289:1724-1730

Yang W, Holland HD (2003) The Hekpoort paleosol in strata 1 at Garborone, Botswana: soil formation during the Great Oxidation Event. Am J Sci 303:187-220

Yasui A, McCready SJ (1998) Alternative repair pathways for UV-induced DNA damage. Bioessays 20(4):291-297

Yu G, Jacobsen SB (2011) Fast accretion of the Earth with a late Moon-forming giant impact. PNAS USA 108(43):17604-9

Zang WL (2007) Deposition and deformation of late Archean sediments and preservation of microfossils in the Harris Greenstone Domain, Gawler Craton, South Australia. Precambrian Res 156:107-124

Zbinden EA, Holland HD, Feakes CR, Dobos SK (1988) The Sturgeon Falls paleosol and the composition of the atmosphere $1.1 \mathrm{Ga}$ BP. Precambrian Res 42:141-163

Zhang J (1992) Observation on algal effects on subaerial karst sedimentation. Geogr Res 11(2):26-33

Zhao B, Robb L, Harris C, Jordaan $L$ (2006) Origin of hydrothermal fluids and gold mineralization associated with the Ventersdorp contact reef, Witwatersrand Basin, South Africa: constraints from S, O, and $\mathrm{H}$ isotopes. In: Reimold WU, Gibson RL (eds) Processes on the early Earth. Geological Society of America special paper 405. Geological Society of America, Boulder, CO, pp 333-352

Zhuravlev AY, Riding R (eds) (2001) The ecology of the Cambrian radiation. Columbia University Press, New York

Zonneveld KAF, Versteegh GJM, Kasten S, Eglinton TI, Emeis KC, Huguet C, Koch BP, De Lange GJ, De Leeuw JW, Middelburg JJ, Mollenhauer G, Prahl FG, Rethemeyer J, Wakeham SG (2010) Selective preservation of organic matter in marine environments; processes and impact on the sedimentary record. Biogeosciences 7:483-511

doi:10.1186/2192-1709-2-1

Cite this article as: Beraldi-Campesi: Early life on land and the first terrestrial ecosystems. Ecological Processes 2013 2:1.

\section{Submit your manuscript to a SpringerOpen ${ }^{\circ}$ journal and benefit from:}

- Convenient online submission

- Rigorous peer review

- Immediate publication on acceptance

- Open access: articles freely available online

- High visibility within the field

- Retaining the copyright to your article

Submit your next manuscript at $\gg$ springeropen.com 